\title{
Mesoporous Assembly of Aluminum Molecular Rings for Iodine Capture
}

Shuyang Yao, ${ }^{\mathrm{ab}}$ Wei-Hui Fang, ${ }^{\mathrm{a} *}$ Yayong Sun, ${ }^{\mathrm{a}}$ San-Tai Wang, ${ }^{\mathrm{a}}$ and Jian Zhang ${ }^{\mathrm{a} *}$

${ }^{a}$ State Key Laboratory of Structural Chemistry, Fujian Institute of Research on the Structure of Matter, Chinese Academy of Sciences, Fuzhou, Fujian 350002, China

${ }^{b}$ University of Chinese Academy of Sciences, Chinese Academy of Sciences, Beijing 100049, China

Email: fwh@fjirsm.ac.cn; zhj@fjirsm.ac.cn.

\section{Content}

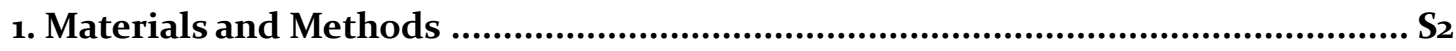

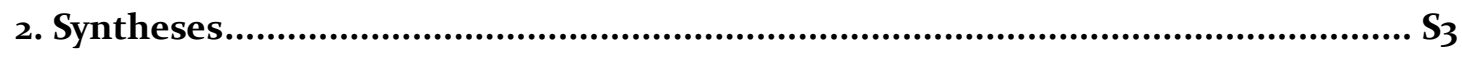

3. The solid-state absorption spectra of molecular rings ......................................... 5

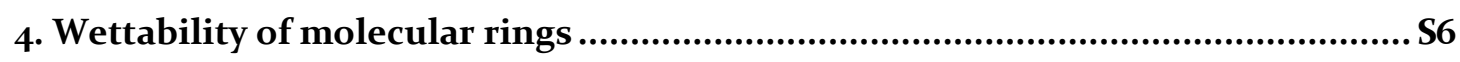

5. Detailed coordination environment information for structures .......................... $S_{7}$

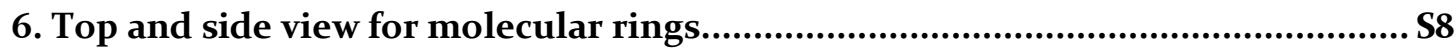

7. Top and side view for molecular cages .................................................................... S10

8. Weak interactions and stacking of molecular cage................................................ S12

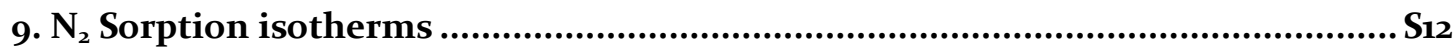

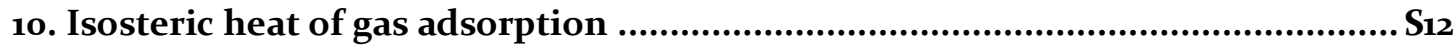

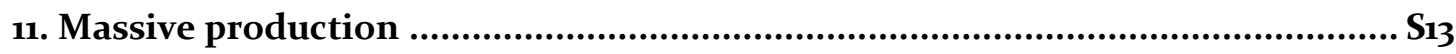

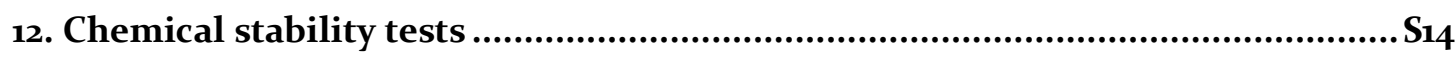

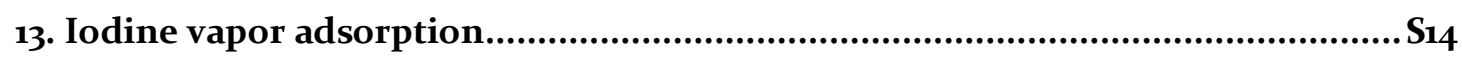

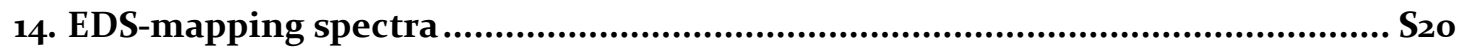

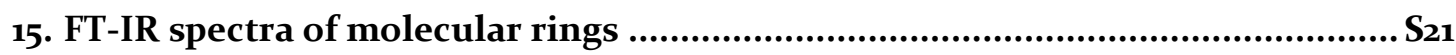

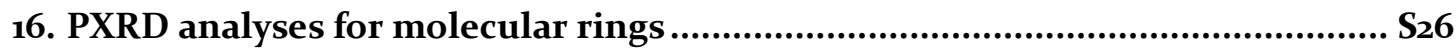

17. Crystallography data for molecular rings.............................................................. S31 


\section{Materials and Methods}

All reagents were commercially and used without further purification. Iodine, benzoic acid derivatives were purchased from Adamas-beta, while aluminium isopropoxide, benzoic acid, p-toluic acid, 4-fluorobenzoic acid, piperazine, pyrazole, 4-methylpyrazole, 4-chloropyrazole, 4-bromopyrazole, 4-iodopyrazole, 3-aminobenzoic acid, lead (II) nitrate, 4-aminobenzoic acid, 3,4-diaminobenzoic acid, 3-furoic acid and 3-thiophenezoic acid were acquired from Aladdin Chemical Reagent Shanghai. Ethanol ( $\geq 99.5 \%)$, isopropyl alcohol ( $\geq 99.5 \%)$, acetonitrile $(\geq 99.5 \%)$, and $\mathrm{N}, \mathrm{N}$-dimethylformamide (DMF, $\geq 99.5 \%$ ) were acquired from Sinopharm Chemical Reagent Beijing. The energy dispersive spectroscopy (EDS) analyses of single crystals were performed on a JEOL JSM670oF field-emission scanning electron microscope equipped with an Oxford INCA system. IR spectra ( $\mathrm{KBr}$ pellets) were recorded on an ABB Bomem MB102 spectrometer over a range $400-4000 \mathrm{~cm}^{-1}$. Thermogravimetric analysis (TGA) was performed on a Mettler Toledo TGA/SDTA $851^{\mathrm{e}}$ analyzer in $\mathrm{N}_{2}$ with a heating rate of $10{ }^{\circ} \mathrm{C} \mathrm{min}^{-1}$ from 20 to 8 oo ${ }^{\circ} \mathrm{C}$. Powder X-ray diffraction (PXRD) data were collected on a Rigaku Mini Flex II diffractometer using CuKa radiation $(\lambda=1.54056 \AA)$ under ambient conditions. The UV-vis diffuse reflection data were recorded at room temperature using a powder sample with $\mathrm{BaSO}_{4}$ as a standard (100 \% reflectance) on a Perkin Elmer Lamda-950 UV spectrophotometer and scanned at $200-800 \mathrm{~nm}$. Analysis of the Raman spectra was performed on Labram HR Evolution Raman microscope equipped with a $785 \mathrm{~nm}$ high-power laser. Temperatures-dependent PXRD data were collected on a Rigaku Ultima-IV diffractometer using CuK $\alpha$ radiation $(\lambda=1.54056 \AA$ ) under $25^{\circ} \mathrm{C}$ to $200{ }^{\circ} \mathrm{C}$. The absorption data are calculated from the Kubelka-Munk function, $\left(F(\mathrm{R})=(1-\mathrm{R})^{2} / 2 \mathrm{R}\right),{ }^{1}$ where $R$ representing the reflectance. ${ }^{27} \mathrm{Al}$ NMR experiments were carried out on a Bruker AVANCE III spectrometer operating at resonance frequencies of $104 \mathrm{MHz}$. The gases adsorption isotherms were measured by using ASAP 2020 volumetric adsorption equipment. Elemental analysis ( $\mathrm{C}$ and $\mathrm{H}$ ) was carried out on a Vario Micro E III analyzer. 


\section{Syntheses}

\section{Synthesis of AlOC-15}

A mixture of aluminium isopropoxide (204 mg, $1 \mathrm{mmol}$ ), benzoic acid (122 $\mathrm{mg}, 1 \mathrm{mmol}$ ), pyrazole (2 g, $29.38 \mathrm{mmol})$ and DMF $(2 \mathrm{~mL})$ was sealed in a $20 \mathrm{~mL}$ vial and transferred to a preheated oven at 100 ${ }^{\circ} \mathrm{C}$ for 3 days. When cooled to room temperature, plate colourless crystals were obtained. (yield: $36 \%$ based on $\left.\mathrm{Al}(\mathrm{OiPr})_{3}\right)$. The crystals are rinsed with $\mathrm{DMF}$ and preserved under a sealed and dry environment. FT-IR $\left(\mathrm{KBr}, \mathrm{cm}^{-1}\right)$ : 3400 $(\mathrm{m}), 1649(\mathrm{~s}), 1604(\mathrm{~s}), 1551(\mathrm{~s}), 1498(\mathrm{~m}), 1430(\mathrm{~s}), 1283(\mathrm{~m}), 1172(\mathrm{w})$, 1051(m), 976(w), 766(w), 717(s), 579(s). Elemental analysis calcd. (\%) for $\mathrm{C}_{80} \mathrm{H}_{72} \mathrm{Al}_{8} \mathrm{~N}_{16} \mathrm{O}_{24}$ (MW 1857.37): C 51.73, H 3.91; found C 50.52, H 3.76.

\section{Synthesis of AlOC-16}

A mixture of aluminium isopropoxide (204 mg, $1 \mathrm{mmol}$ ), 3-aminobenzoic acid (137.14 mg, $1 \mathrm{mmol}$ ) and pyrazole $(2 \mathrm{~g}, 29.38 \mathrm{mmol})$ was sealed in a $20 \mathrm{~mL}$ vial and heated at $100{ }^{\circ} \mathrm{C}$ for 3 days. When cooled to room temperature, colourless crystals were obtained after rinsed with ethanol and preserved under a sealed and dry environment. (yield: $11 \%$ based on $\left.\mathrm{Al}(\mathrm{OiPr})_{3}\right)$. FT-IR $\left(\mathrm{KBr}, \mathrm{cm}^{-1}\right): 3383(\mathrm{~m})$, $1625(\mathrm{~s}), 1585(\mathrm{~s}), 154 \mathrm{o}(\mathrm{s}),{ }_{1417}(\mathrm{~m}),{ }_{1055}(\mathrm{~s}), 785(\mathrm{~m})$. Elemental analysis calcd. (\%) for $\mathrm{C}_{80} \mathrm{H}_{80} \mathrm{Al}_{8} \mathrm{~N}_{24} \mathrm{O}_{24}$ (MW 1977.49): C 48.59, H 4.07; found C 48.63, H 4.11.

\section{Synthesis of AlOC-17}

A mixture of aluminium isopropoxide (204 mg, 1 mmol), 4-aminobenzoic acid (137.14 mg, $1 \mathrm{mmol}$ ), pyrazole $(2 \mathrm{~g}, 29.38 \mathrm{mmol})$, acetonitrile $(2 \mathrm{~mL})$ was sealed in a $20 \mathrm{~mL}$ vial and transferred to a preheated oven at $100{ }^{\circ} \mathrm{C}$ for 3 days. The addition of piparazine or alcohols (isopropanol, n-butyl alcohol etc.) improved the production. When cooled to room temperature, block light yellow crystals were obtained. (yield: $48 \%$ based on $\left.\mathrm{Al}(\mathrm{OiPr})_{3}\right)$. The crystals are rinsed with isopropyl alcohol and preserved under a sealed and dry environment. FT-IR $\left(\mathrm{KBr}, \mathrm{cm}^{-1}\right): 3383(\mathrm{~m}), 162 \mathrm{o}(\mathrm{s}), 1588(\mathrm{~s}), 1538(\mathrm{~s})$, ${ }_{1417}(\mathrm{~m}), 1056(\mathrm{~s}), 786(\mathrm{~m})$. Elemental analysis calcd. (\%) for $\mathrm{C}_{80} \mathrm{H}_{88} \mathrm{Al}_{8} \mathrm{~N}_{24} \mathrm{O}_{24}$ (MW 1985.55): C 48.39, H 4.47; found $\mathrm{C} 47.96, \mathrm{H} 4.26$.

\section{Synthesis of AlOC-18}

A mixture of aluminium isopropoxide (204 mg, $1 \mathrm{mmol}$ ), 3,4-diaminobenzoic acid (152.15 mg, 1 $\mathrm{mmol}$ ) and pyrazole ( $2 \mathrm{~g}, 29.38 \mathrm{mmol})$ was sealed in a $20 \mathrm{~mL}$ vial and transferred to a preheated oven at $100{ }^{\circ} \mathrm{C}$ for 3 days. When cooled to room temperature, rinsed with ethanol, reddish brown crystals were obtained. (yield: $13 \%$ based on $\left.\mathrm{Al}(\mathrm{OiPr})_{3}\right)$. The crystals are preserved in a sealed and dry environment. FT-IR ( $\left.\mathrm{KBr}, \mathrm{cm}^{-1}\right): 3385(\mathrm{~m}), 1625(\mathrm{~s}), 1588(\mathrm{~s}), 154 \mathrm{o}(\mathrm{s}), 1415(\mathrm{~m}), 106 \mathrm{o}(\mathrm{s}), 785(\mathrm{~m})$. Elemental analysis calcd. (\%) for $\mathrm{C}_{80} \mathrm{H}_{90} \mathrm{Al}_{8} \mathrm{~N}_{32} \mathrm{O}_{25}$ (MW 2115.62): $\mathrm{C} 45.42, \mathrm{H}$ 4.29; found $\mathrm{C} 45.86, \mathrm{H} 4.36$.

\section{Synthesis of AlOC-19-AlOC-21}

A mixture of aluminium isopropoxide (204 mg, $1 \mathrm{mmol}$ ), 4-methyl benzoic acid or 4-fluorobenzoic acid or 3-furoic acid (136.15 mg, 1 mmol; $140.11 \mathrm{mg}, 1 \mathrm{mmol}$; $112.08 \mathrm{mg}$, $1 \mathrm{mmol}$ ), pyrazole (2 g, 29.38 mmmol) and DMF ( $2 \mathrm{~mL}$ ) was sealed in a $20 \mathrm{~mL}$ vial and transferred to a preheated oven at $100{ }^{\circ} \mathrm{C}$ for 3 days. (yield: $46 \% ; 42 \% ; 48 \%$ based on $\mathrm{Al}\left((\mathrm{OiPr})_{3}\right)$. AlOC-19-FT-IR $\left(\mathrm{KBr}, \mathrm{cm}^{-1}\right): 3375(\mathrm{~m}), 2929(\mathrm{~m})$, 1650(s), 1430(s), $1065(\mathrm{~s}), 842(\mathrm{~s}), 574(\mathrm{~s})$. AlOC-2o- FT-IR $\left(\mathrm{KBr}, \mathrm{cm}^{-1}\right): 3375(\mathrm{~m}), 2932(\mathrm{~m}), 1655(\mathrm{~s}), 1425(\mathrm{~s})$, 1067(s), 835(s), 574(s). AlOC-21- FT-IR (KBr, cm $\left.{ }^{-1}\right)$ :3328(m), 2375(w), 1662(s), $1573(\mathrm{~m}), 1438(\mathrm{~m}), 783(\mathrm{~s})$. 
Elemental analysis calcd. (\%) for $\mathrm{C}_{88} \mathrm{H}_{88} \mathrm{Al}_{8} \mathrm{~N}_{16} \mathrm{O}_{24}$ (MW 1969.59): $\mathrm{C}$ 53.66, $\mathrm{H}$ 4.50; found $\mathrm{C}$ 53.45, $\mathrm{H}$ 4.21. Elemental analysis calcd. (\%) for $\mathrm{C}_{80} \mathrm{H}_{70} \mathrm{Al}_{8} \mathrm{~N}_{16} \mathrm{O}_{27} \mathrm{~F}_{8}$ (MW 2055.34): $\mathrm{C} 46.75$, $\mathrm{H}$ 3.43; found C 46.45, $\mathrm{H}$ 3.21. Elemental analysis calcd. (\%) for $\mathrm{C}_{64} \mathrm{H}_{56} \mathrm{Al}_{8} \mathrm{~N}_{16} \mathrm{O}_{32}(\mathrm{MW}$ 1777.07): $\mathrm{C}$ 43.25, $\mathrm{H}$ 3.18; found $\mathrm{C}$ 43.06, H 2.97 .

\section{Synthesis of AlOC-22-AlOC-25}

A mixture of aluminium isopropoxide (204 mg, $1 \mathrm{mmol})$, 4-methylpyrazole (4 g, $48.78 \mathrm{mmol})$, benzoic acid or p-toluic acid or 3-thiophenezoic acid or 3-furoic acid (122 mg, $1 \mathrm{mmol}$; $136.15 \mathrm{mg}, 1$ mmol; $128.15 \mathrm{mg}, 1 \mathrm{mmol}$; $112.08 \mathrm{mg}, 1 \mathrm{mmol})$, and DMF $(2 \mathrm{~mL})$ was sealed in a $20 \mathrm{~mL}$ vial and transferred to a preheated oven at $100{ }^{\circ} \mathrm{C}$ for 3 days. (yield: $13 \% ; 46 \% ; 32 \% ; 38 \%$ based on $\mathrm{Al}(\mathrm{OiPr}){ }_{3}$ ). The crystals are rinsed with DMF and preserved under a sealed and dry environment. AlOC-22-FT-IR $\left(\mathrm{KBr}, \mathrm{cm}^{-1}\right): 3325(\mathrm{~m}), 1620(\mathrm{~s}), 1417(\mathrm{~m}), 1052(\mathrm{~s}), 786(\mathrm{~m})$. AlOC-23-FT-IR $\left(\mathrm{KBr}, \mathrm{cm}^{-1}\right): 3365(\mathrm{~m}), 2829(\mathrm{~m})$, 1650(s), 1430(s), 1035(s), 594(s). AlOC-24- FT-IR (KBr, cm $\left.{ }^{-1}\right):$ 3238(m), 2829(w), 1658(s), 1448(m), 992(w), 753(s). AlOC-25-FT-IR (KBr, cm $\left.{ }^{-1}\right)$ : 3442(w), 2829(m), 1658(s), 1570(s), $782(\mathrm{~m}), 659(\mathrm{~s})$. Elemental analysis calcd. (\%) for $\mathrm{C}_{88} \mathrm{H}_{88} \mathrm{Al}_{8} \mathrm{~N}_{16} \mathrm{O}_{24}$ (MW 1969.59): $\mathrm{C}$ 53.66, $\mathrm{H}$ 4.50; found $\mathrm{C}$ 53.62, $\mathrm{H}$ 4.45. Elemental analysis calcd. (\%) for $\mathrm{C}_{96} \mathrm{H}_{104} \mathrm{Al}_{8} \mathrm{~N}_{16} \mathrm{O}_{24}$ (MW 2081.80): C 55.39, $\mathrm{H}$ 5.04; found C 55.45, $\mathrm{H}$ 5.21. Elemental analysis calcd. (\%) for $\mathrm{C}_{72} \mathrm{H}_{72} \mathrm{Al}_{8} \mathrm{~N}_{16} \mathrm{O}_{24} \mathrm{~S}_{8}$ (MW 2017.81): $\mathrm{C}$ 42.86, $\mathrm{H}$ 3.60; found $\mathrm{C}$ 43.06, $\mathrm{H}$ 3.77. Elemental analysis calcd. (\%) for $\mathrm{C}_{72} \mathrm{H}_{72} \mathrm{Al}_{8} \mathrm{~N}_{16} \mathrm{O}_{32}$ (MW 1889.28): $\mathrm{C}$ 45.77, $\mathrm{H}$ 3.84; found C $45.06, \mathrm{H} 3.77$.

\section{Synthesis of AlOC-26-NC}

A mixture of aluminium isopropoxide $(204 \mathrm{mg}, 1 \mathrm{mmol})$, 4-methylpyrazole (4 g, $48.72 \mathrm{mmol}$ ), benzoic acid (122 mg, $1 \mathrm{mmol})$, piperazine (86.14 $\mathrm{mg}, 1 \mathrm{mmol}$ ) and DMF ( $2 \mathrm{~mL}$ ) was sealed in a $20 \mathrm{~mL}$ vial and transferred to a preheated oven at $100{ }^{\circ} \mathrm{C}$ for 3 days. When cooled to room temperature, octahedron colourless crystals were obtained. (yield: $56 \%$ based on $\left.\mathrm{Al}(\mathrm{OiPr})_{3}\right)$. The crystals were obtained after rinsed with DMF and preserved under a sealed and dry environment. FT-IR $\left(\mathrm{KBr}, \mathrm{cm}^{-1}\right)$ : $3327(\mathrm{~m}), 1620(\mathrm{~s}), 1415(\mathrm{~m}), 1050(\mathrm{~s}), 776(\mathrm{~m})$ Elemental analysis calcd. (\%) for $\mathrm{C}_{88} \mathrm{H}_{88} \mathrm{Al}_{8} \mathrm{~N}_{16} \mathrm{O}_{24}$ (MW 1969.58): C 53.66, H 4.50; found C 53.62, H 4.35.

\section{Synthesis of AlOC-27-NC-AlOC-29-NC}

A mixture of aluminium isopropoxide (204 mg, $1 \mathrm{mmol}$ ), 4-chloropyrazole or 4-bromopyrazole or 4-iodopyrazole (300 mg, $2.93 \mathrm{mmol} ; 300 \mathrm{mg}, 2.04 \mathrm{mmol}$; $300 \mathrm{mg}, 1.55 \mathrm{mmol}$ ), benzoic acid (122 mg, 1 mmol), piperazine (86.14 mg, $1 \mathrm{mmol}$ ), lead (II) nitrate (128mg,o $.33 \mathrm{mmol})$ and DMF (2 mL) was sealed in a $20 \mathrm{~mL}$ vial and transferred to a preheated oven at $105{ }^{\circ} \mathrm{C}$ for 4 days. When cooled to room temperature, octahedron colourless crystals were obtained. (yield: $48 \%$; $24 \%$; $12 \%$ based on $\left.\mathrm{Al}(\mathrm{OiPr})_{3}\right)$. The crystals were obtained after rinsed with DMF and preserved under a sealed and dry environment. AlOC-27-NC-FT-IR (KBr, $\left.\mathrm{cm}^{-1}\right)$ : 3215(s), 1555(s), 1476(m), $1078(\mathrm{~s}), 838(\mathrm{~s}), 650(\mathrm{~s})$. AlOC-28-NC-FT-IR (KBr, cm $\left.{ }^{-1}\right): 3243(\mathrm{~m}), 1645(\mathrm{~s}), 1426(\mathrm{~m}), 1178(\mathrm{~s}), 838(\mathrm{~s}), 786(\mathrm{~s})$. AlOC-29-NC- FT-IR $\left(\mathrm{KBr}, \mathrm{cm}^{-1}\right): 3378(\mathrm{~m}), 1615(\mathrm{~s}), 1555(\mathrm{~s}), 1421(\mathrm{~m}), 1128(\mathrm{~s}), 758(\mathrm{~m})$. Elemental analysis calcd. (\%) for $\mathrm{C}_{88} \mathrm{H}_{88} \mathrm{Al}_{8} \mathrm{~N}_{16} \mathrm{O}_{24} \mathrm{Cl}_{8}$ (MW 2253.21): C 46.91, $\mathrm{H}$ 3.94; found $\mathrm{C} 46.62, \mathrm{H}$ 3.85. Elemental analysis calcd. (\%) for $\mathrm{C}_{88} \mathrm{H}_{88} \mathrm{Al}_{8} \mathrm{~N}_{16} \mathrm{O}_{24} \mathrm{Br}_{8}$ (MW 2608.82): $\mathrm{C}$ 40.51, $\mathrm{H}$ 3.40; found $\mathrm{C} 40.62, \mathrm{H}$ 3.55. Elemental analysis calcd. 
(\%) for $\mathrm{C}_{88} \mathrm{H}_{88} \mathrm{Al}_{8} \mathrm{~N}_{16} \mathrm{O}_{24} \mathrm{I}_{8}\left(\mathrm{MW} 2984.82\right.$ ): $\mathrm{C}$ 35.41, $\mathrm{H}$ 2.97; found $\mathrm{C}_{35.62}, \mathrm{H}$ 3.15.

\section{X-ray Crystallographic Analyses}

Crystallographic data of crystal AlOC-15, AlOC-18 and AlOC-21 were collected on Supernova single crystal diffractometer equipped with graphite-monochromatic $\mathrm{Cu}-\mathrm{K} \alpha$ radiation $(\lambda=1.54184 \AA)$ at about $150 \mathrm{~K}, 100 \mathrm{~K}$ and $100 \mathrm{~K}$. Crystallographic data of crystal AlOC-16, AlOC-17, AlOC-24, AlOC-26-NC were collected on Hybrid Pixel Array detector equipped with Ga-K $\alpha$ radiation $(\lambda=1.3405$ Å) at about $100 \mathrm{~K}$; AlOC-19, AlOC-20, AlOC-23, AlOC-25, AlOC-27-NC, AlOC-29-NC, I @AlOC-27-NC were at about $100 \mathrm{~K}$; AlOC-22, AlOC-28-NC were at $298 \mathrm{~K}$ and $\mathrm{I}_{2} @ A l O C-28-\mathrm{NC}$ was at $120 \mathrm{~K}$. The structures were solved with the dual-direct methods using ShelxT and refined with the full-matrix least-squares technique based on $F^{2}$ using the SHELXL-2014. ${ }^{2}$ Non-hydrogen atoms were refined anisotropically. Hydrogen atoms were added theoretically, riding on the concerned atoms and refined with fixed thermal factors. All absorption corrections were performed using the multi-scan program. The obtained crystallographic data for these molecular rings are summarized in Table S2 to Table S6.

\section{Iodine Adsorption}

Prior to adsorption, the as-synthesized samples were treated with methanol solvent exchange for 3 days, and then activated under vacuum for 6 hours at $150{ }^{\circ} \mathrm{C}$. The activated sample was then transferred into a vessel, which contained a small amount of solid $I_{2}$ in an open vial at ambient pressure. The vessel was then sealed and heated at $80{ }^{\circ} \mathrm{C}$ to allow adsorption of vapour iodine into the desolvated AlOCs.

\section{Reference:}

1. W. W. Wendlandt and H. G. Hecht., Reflectance Spectroscopy, Interscience, New York, 1966, p.

2. G. M. Sheldrick., Acta Cryst. C. 2015, 71, 3-8.

\section{The solid-state absorption spectra of molecular rings}
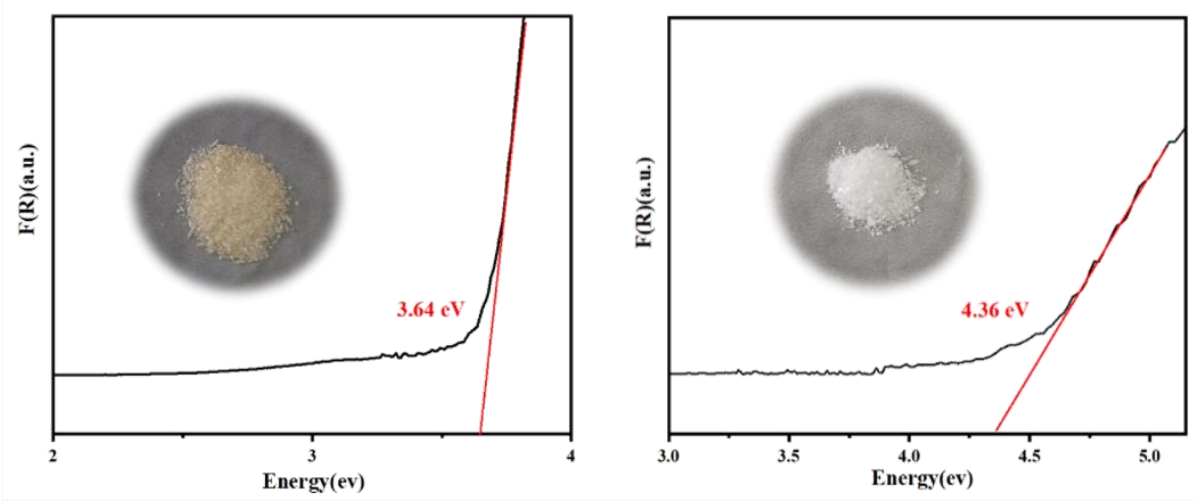

Figure. S1 The solid-state absorption spectra of AlOC-17 (left) and AlOC-21 (right). 

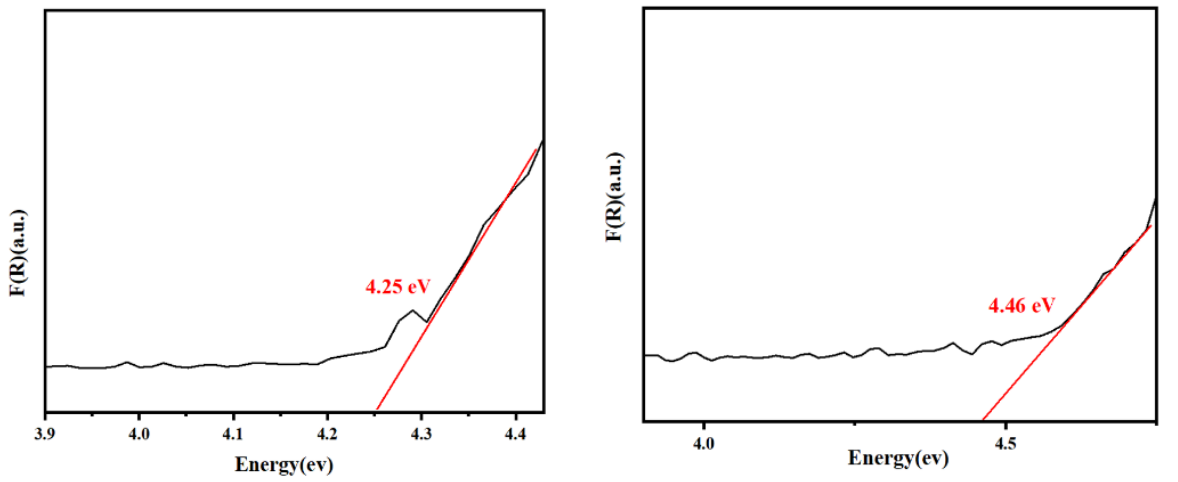

Figure. S2 The solid-state absorption spectra of AlOC-23 (left) and AlOC-25 (right).

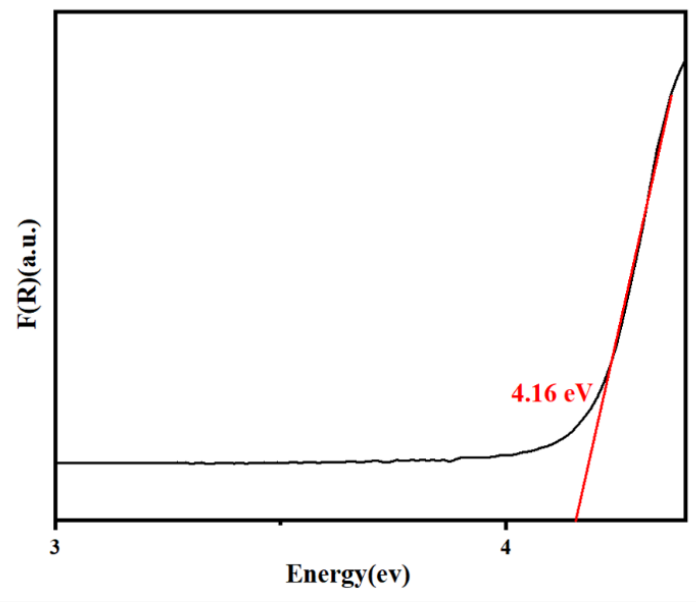

Figure. S3 The solid-state absorption spectra of AlOC-26-NC.

\section{Wettability of molecular rings}
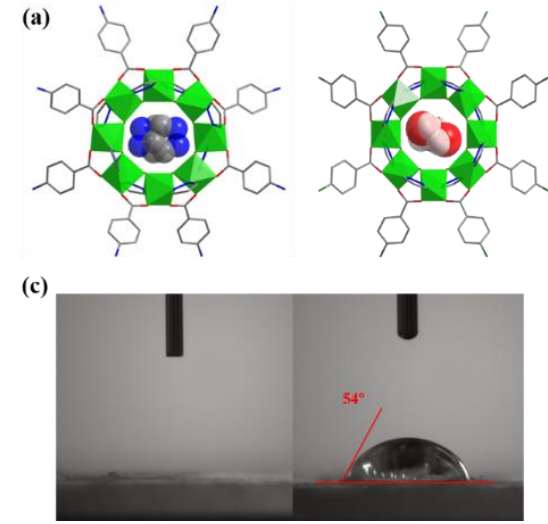

(b)

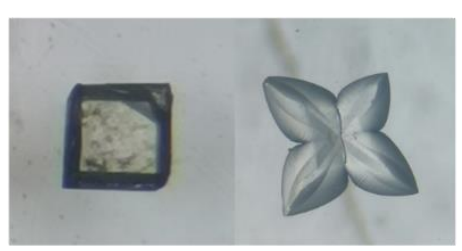

(d)

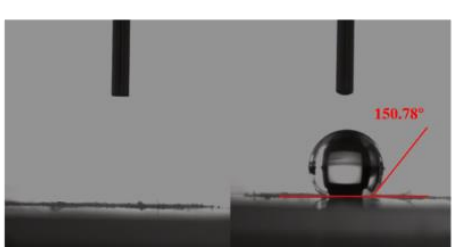

Figure. S4 (a) Structures of AlOC-17 (left) and AlOC-20 (right) - showing the position of the guest pyrazole and water molecules which is the co-occupy form in ring center. Parts of hydrogen atoms are omitted for clarity. (b) Photos of AlOC-17 (left) and AlOC-2o (right) under microscope. (c) Contact angle patterns for AlOC-17. The contact angle measured on as-synthesized powder samples at room temperature of AlOC-17 was $54^{\circ}$, indicating its hydrophilicity. (d) Contact angle patterns for AlOC-20. The contact angle measured on as-synthesized powder samples at room temperature of AlOC-2o was 
$150.78^{\circ}$, indicating its super-hydrophobicity. Color codes: green $\mathrm{Al}$, red $\mathrm{O}$, blue $\mathrm{N}$, gray $\mathrm{C}$, cyan $\mathrm{F}$, white $\mathrm{H}$.

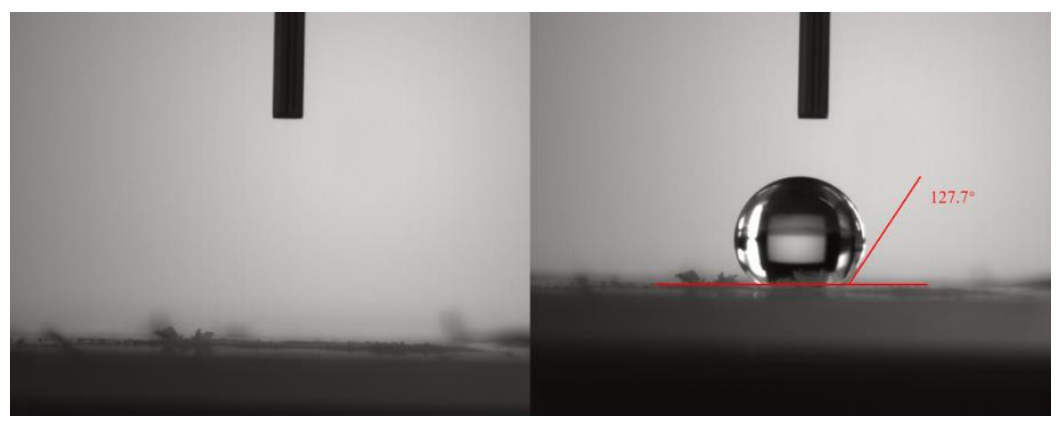

Figure. S5 Contact angle patterns for AlOC-15. The contact angle measured on as-synthesized powder samples at room temperature of AlOC-15 was $127.7^{\circ}$, indicating its superhydrophobicity.

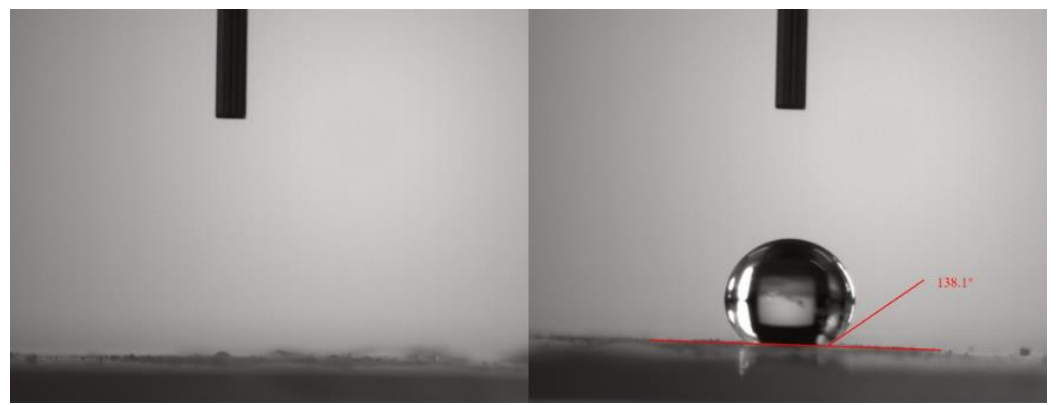

Figure. S6 Contact angle patterns for AlOC-23. The contact angle measured on as-synthesized powder samples at room temperature of AlOC-23 was $138.1^{\circ}$, indicating its superhydrophobicity.

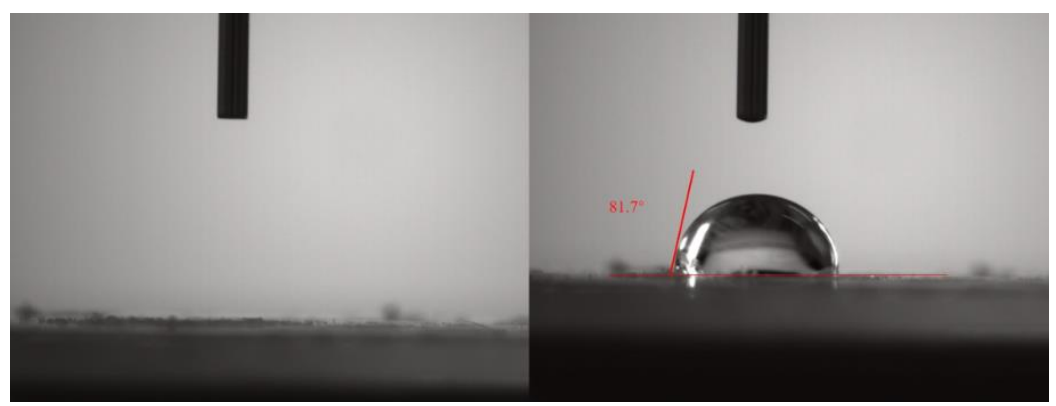

Figure. S7 Contact angle patterns for AlOC-24. The contact angle measured on as-synthesized powder samples at room temperature of AlOC-24 was $81.7^{\circ}$, indicating its hydrophilicity.

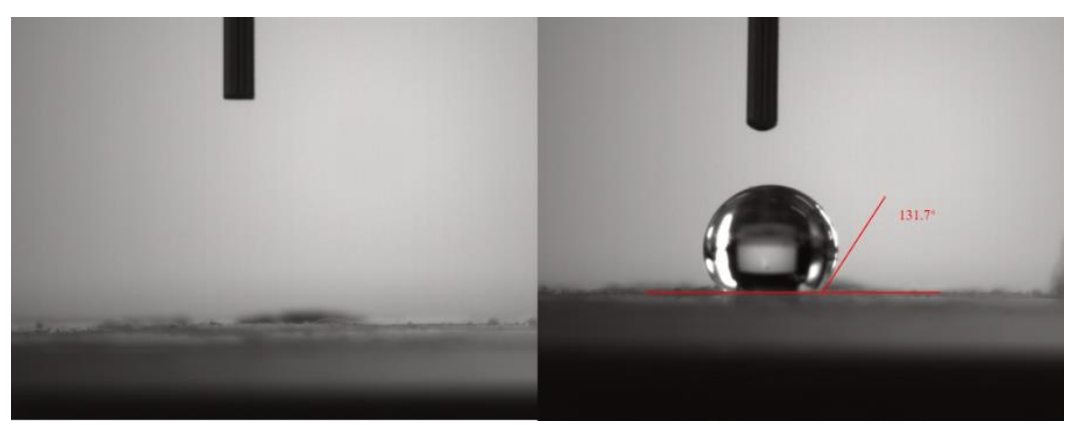

Figure. S8 Contact angle patterns for AlOC-26-NC. The contact angle measured on as-synthesized powder samples at room temperature of AlOC-26-NC was $131.7^{\circ}$, indicating its superhydrophobicity.

\section{Detailed coordination environment information for structures}




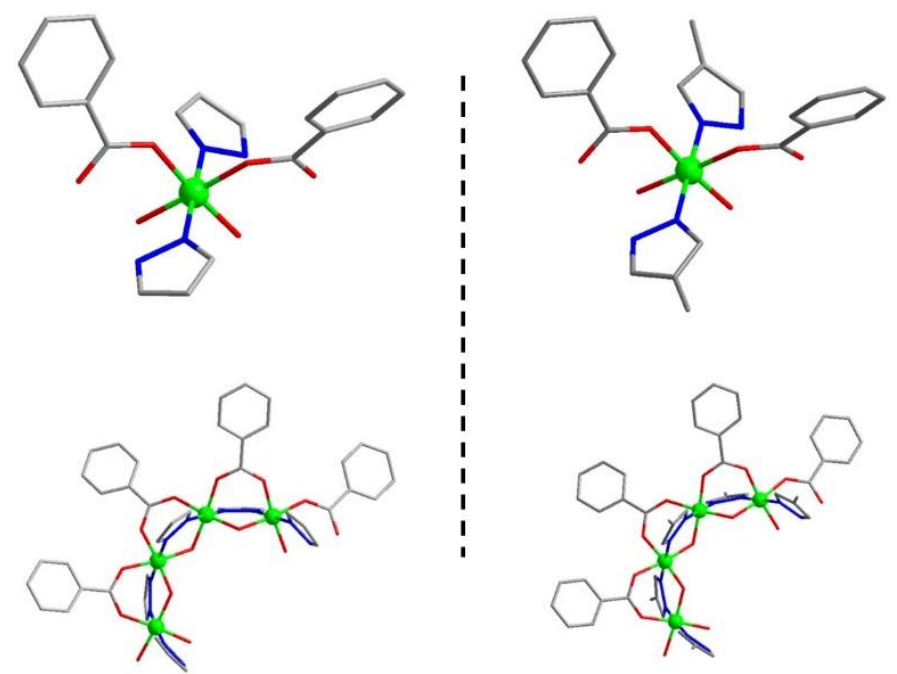

Figure.S9 Coordination environment and linkages between neighbouring $\mathrm{Al}^{3+}$ ions: (left) AlOC-15 and (right) AlOC-22, respectively.

\section{Top and side view for molecular rings}
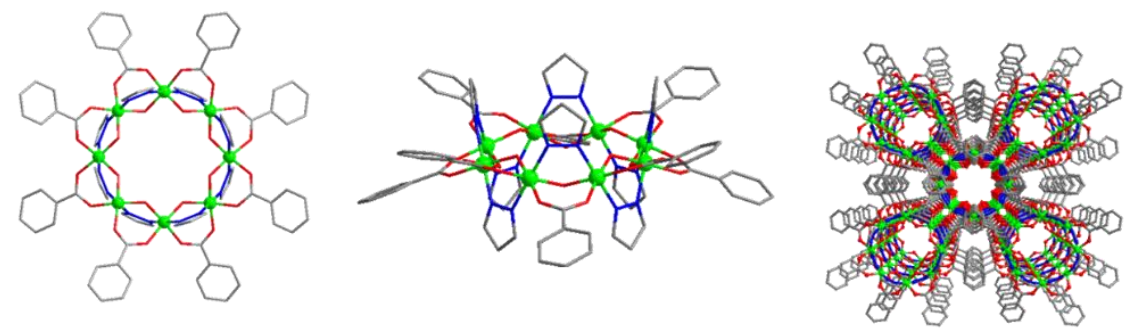

Figure.S1o Top (left), side (middle) and packing view (right) of AlOC-15.
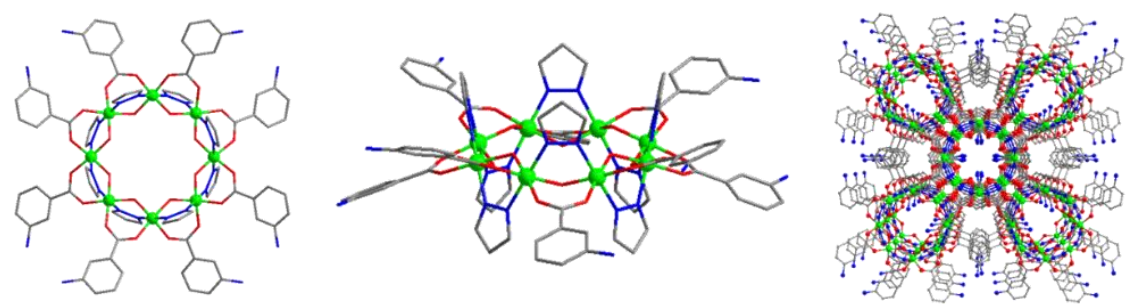

Figure.Sı Top (left), side (middle) and packing view (right) of AlOC-16.
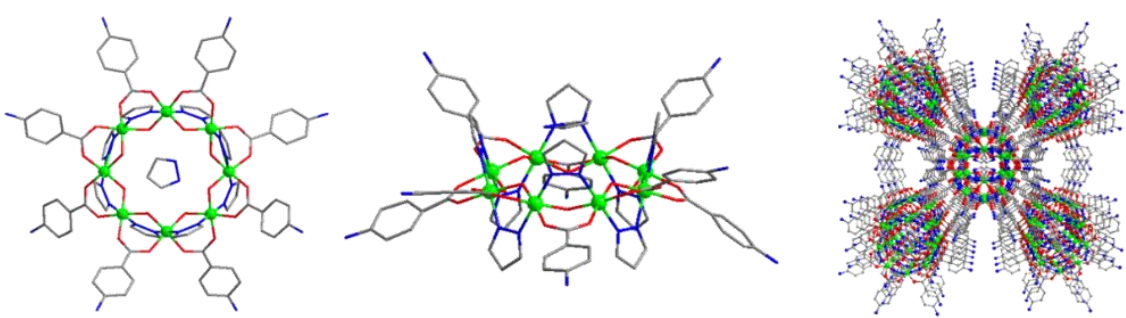

Figure.S12 Top (left), side (middle) and packing view (right) of AlOC-17. 

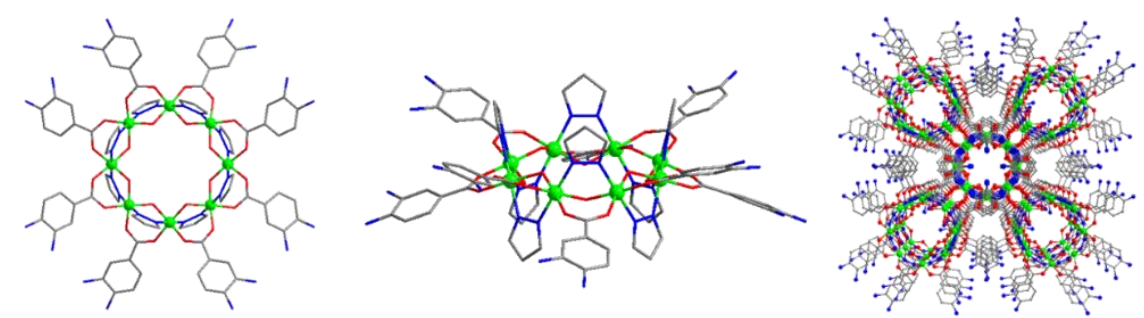

Figure.S13 Top (left), side (middle) and packing view (right) of AlOC-18, the guest water molecules are omitted for clarity.
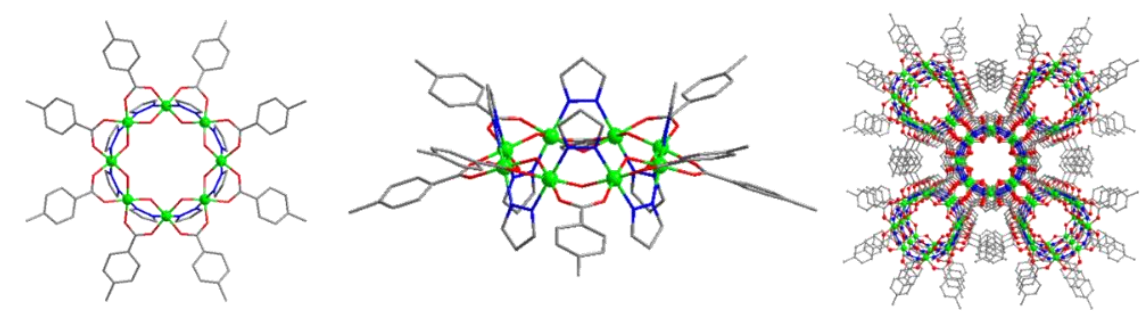

Figure.S14 Top (left), side (middle) and packing view (right) of AlOC-19.
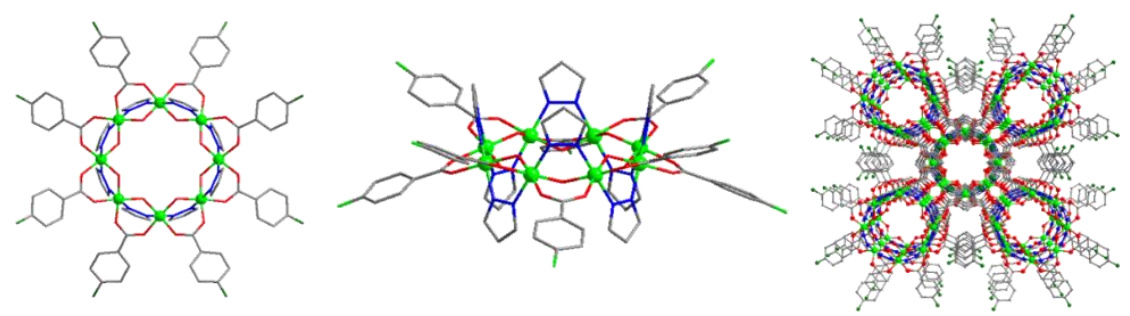

Figure.S15 Top (left), side (middle) and packing view (right) of AIOC-2o, the guest water molecules are omitted for clarity.
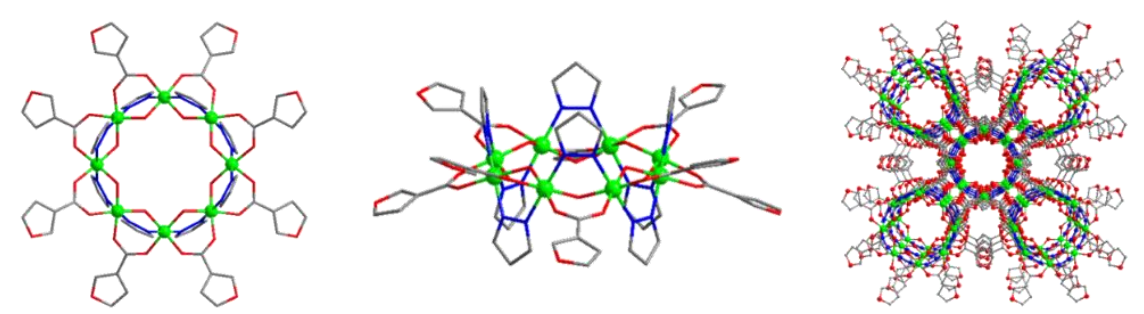

Figure.S16 Top (left), side (middle) and packing view (right) of AlOC-21.
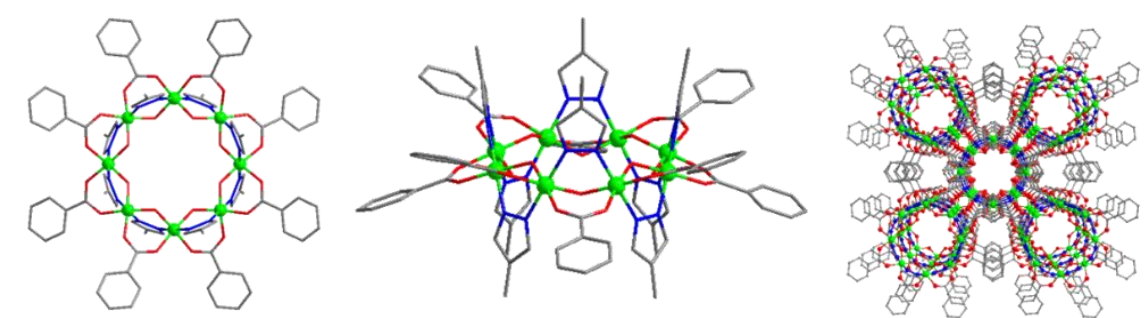

Figure.S17 Top (left), side (middle) and packing view (right) of AlOC-22. 

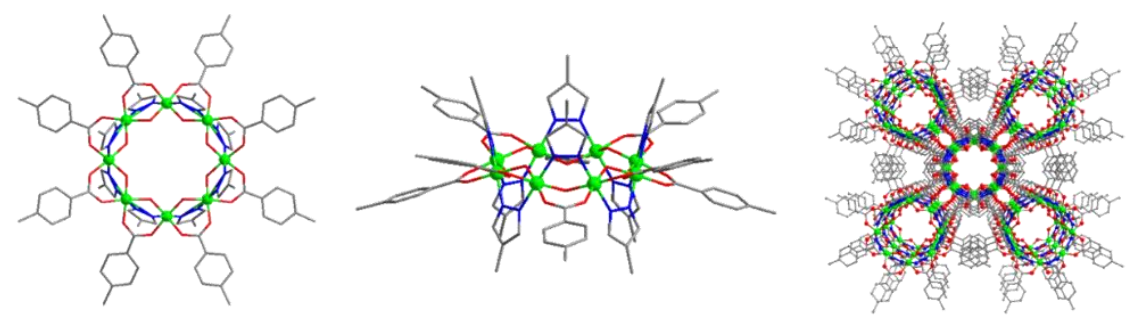

Figure.S18 Top (left), side (middle) and packing view (right) of AlOC-23.
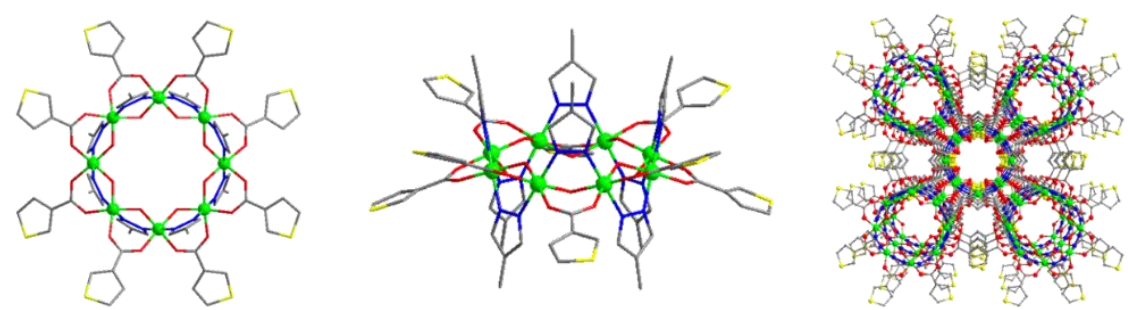

Figure.S19 Top (left), side (middle) and packing view (right) of AlOC-24.
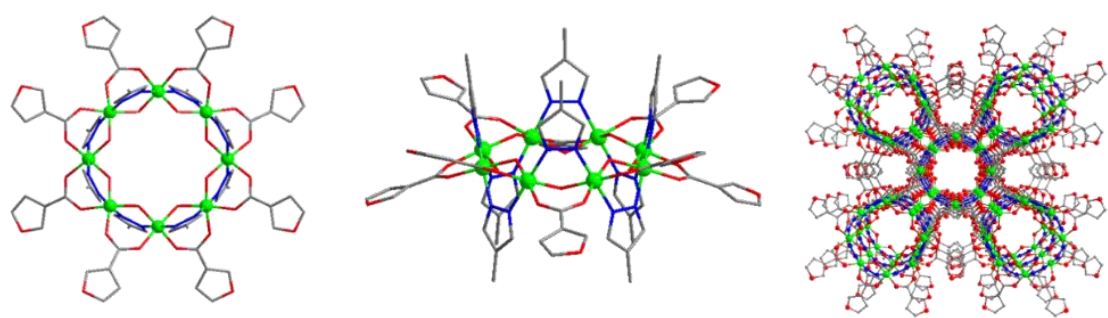

Figure.S2o Top (left), side (middle) and packing view (right) of AlOC-25.

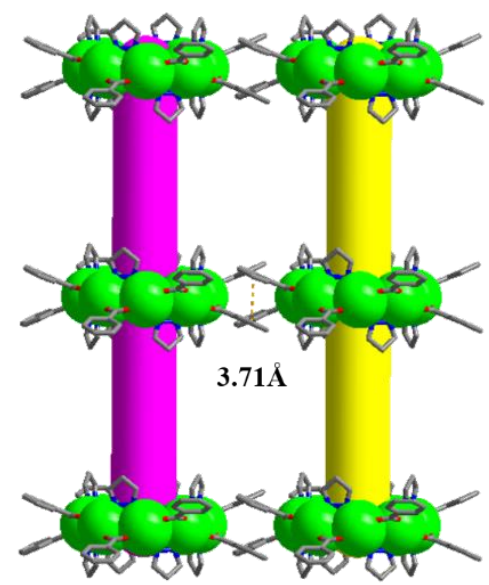

Figure. S21 The $\pi \cdots \pi$ stacking interactions between molecular rings in AlOC-15. 


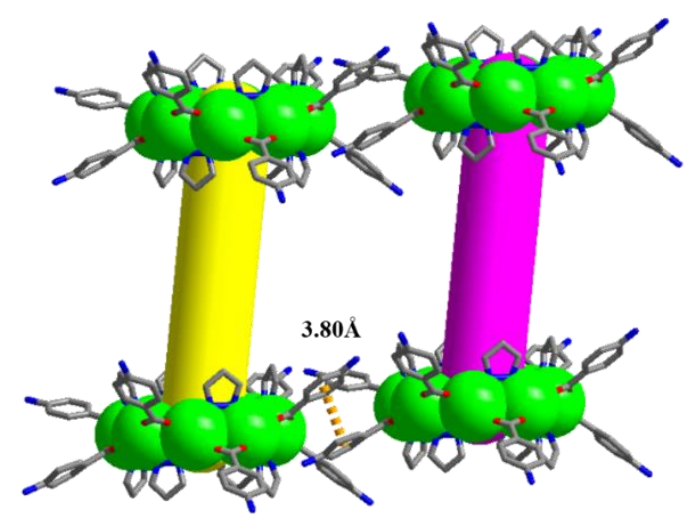

Figure. S22 The $\pi \cdots \pi$ stacking interactions between molecular rings in AlOC-17.

\section{Top and side view for molecular cages}
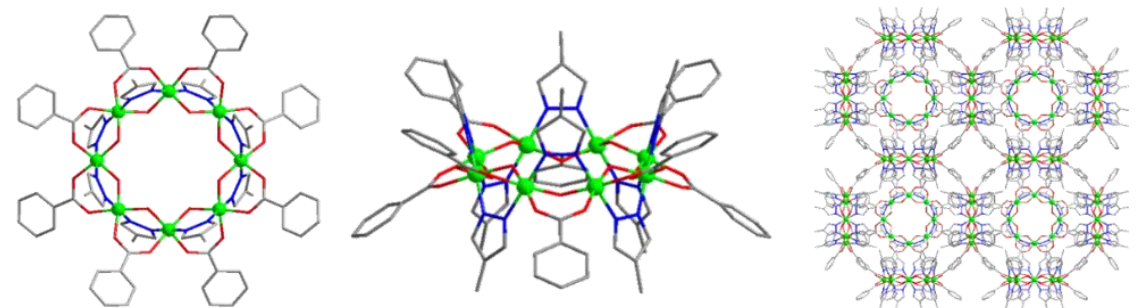

Figure.S23 Top (left), side (middle) and packing view (right) of AlOC-26-NC.
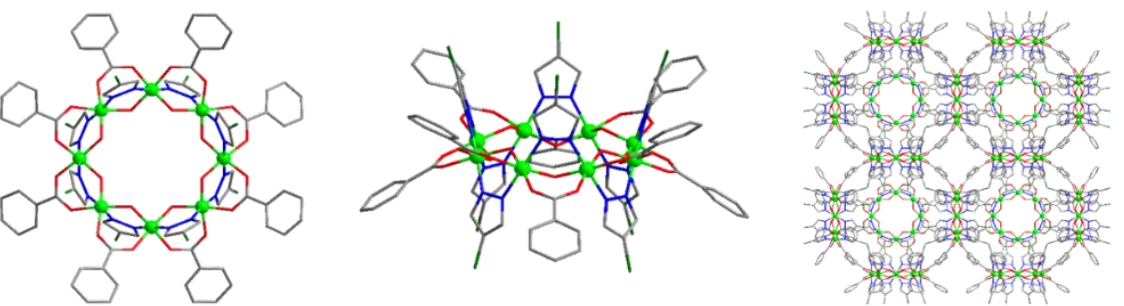

Figure.S24 Top (left), side (middle) and packing view (right) of AlOC-27-NC.
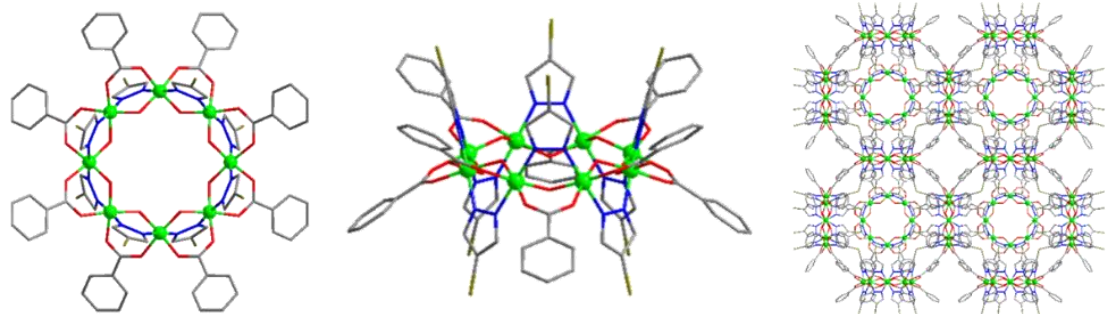

Figure.S25 Top (left), side (middle) and packing view (right) of AlOC-28-NC 

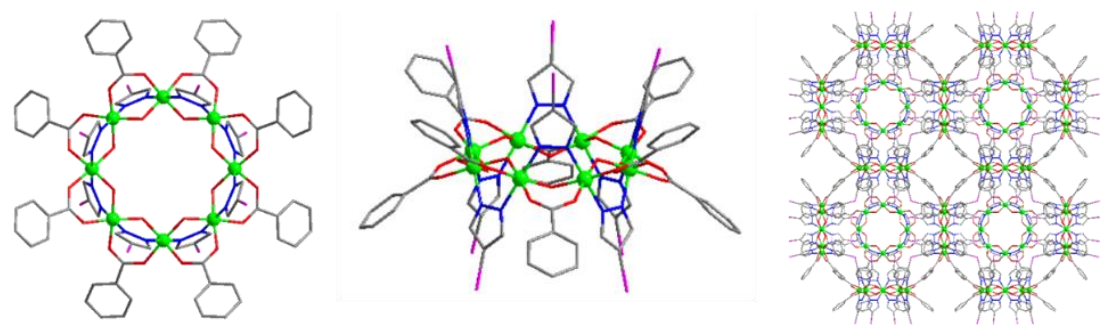

Figure.S26 Top (left), side (middle) and packing view (right) of AlOC-29-NC.

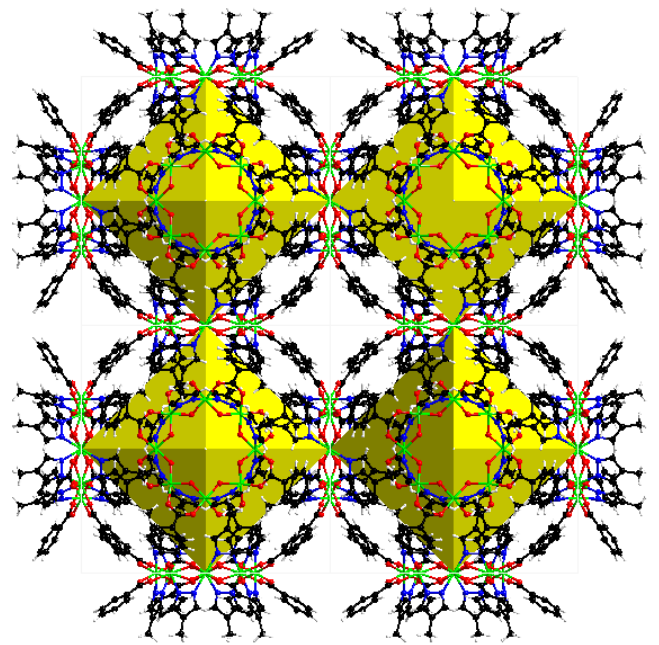

Figure.S27 The packing view of AlOC-26-NC.

\section{Weak interactions and stacking of molecular cage}

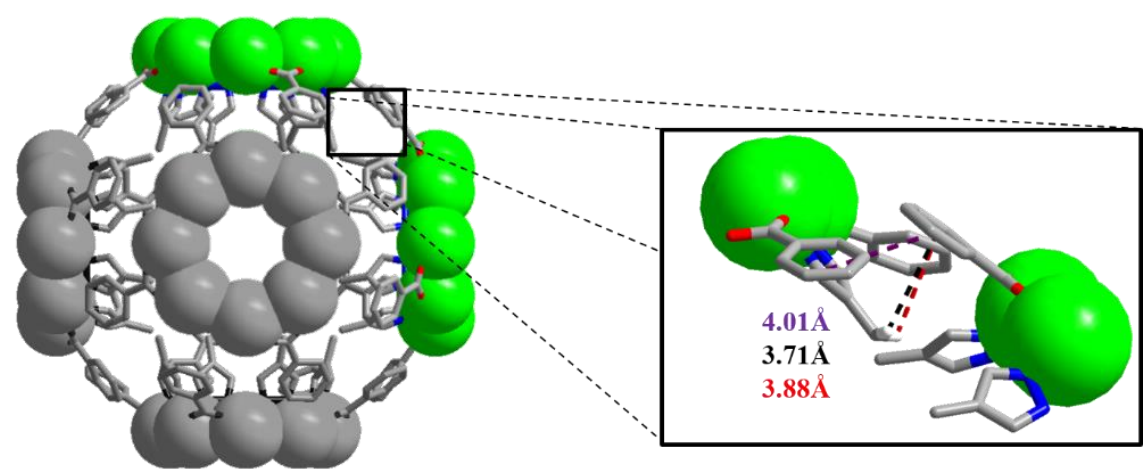

Figure. S28 The C-H $\cdots \pi$ and $\pi \cdots \pi$ stacking interactions between molecular rings in AlOC-26-NC. 

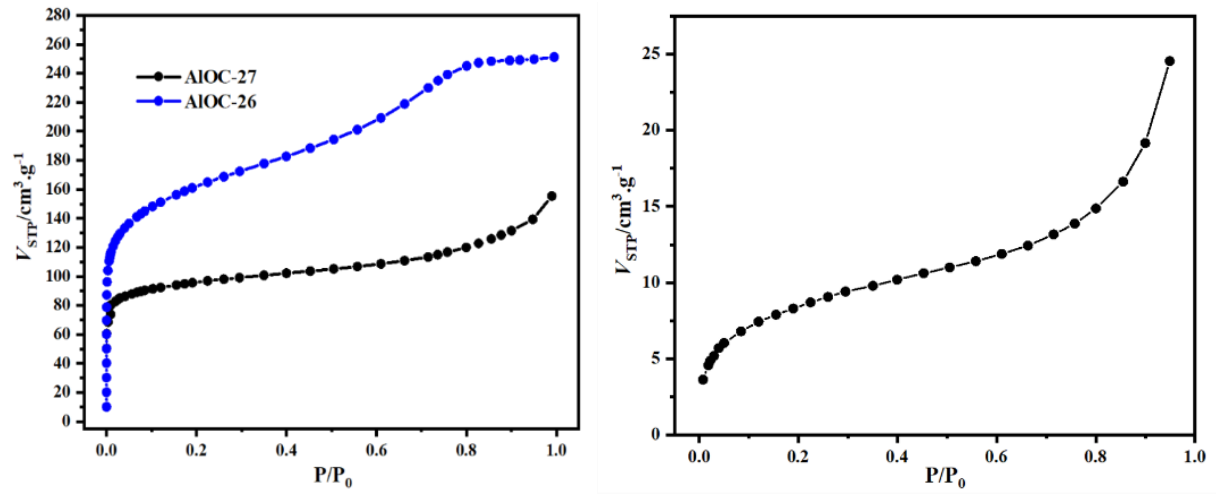

Figure. S29 Sorption isotherms measured on AlOC-26-NC, AlOC-27-NC (left) and AlOC-15 (right) for $\mathrm{N}_{2}$ at $77 \mathrm{~K}$.

\section{Isosteric heat of gas adsorption}

The gas sorption data for AlOC-26-NC and AlCO-27-NC were measured up to 1 bar at different temperatures were fitted by the virial equation (1) to estimate the enthalpy of adsorption.

$$
\ln (p)=\ln (n)+\mathbf{1} / \mathbf{T}\left(A_{o}+A_{1} n+A_{2} n^{2}+\ldots\right)+\left(b_{o}+b_{1} n+b_{2} n^{2}+b_{3} n^{3}+\ldots\right)
$$

Where $P$ is pressure, $N$ is amount adsorbed, $T$ is temperature, $A_{0}, A_{1}$ and $A_{2} \ldots$ and $b_{0} b_{1} b_{2} \ldots$ are temperature independent empirical parameters.

The isosteric heat of adsorption was estimated from the following equation (2) as a function of $\mathrm{H}_{2}$ uptake.

$$
Q_{s t}=-R\left(A_{o}+A_{1} \mathbf{n}+A_{2} n^{2}+\ldots\right)
$$

Here, $\mathbf{Q}_{\mathrm{st}}$ is the coverage-dependent isosteric heat of adsorption and $R$ is the universal gas constant of $8.314 \mathrm{~J} \mathrm{~K}^{-1} \mathrm{~mol}^{-1}$.

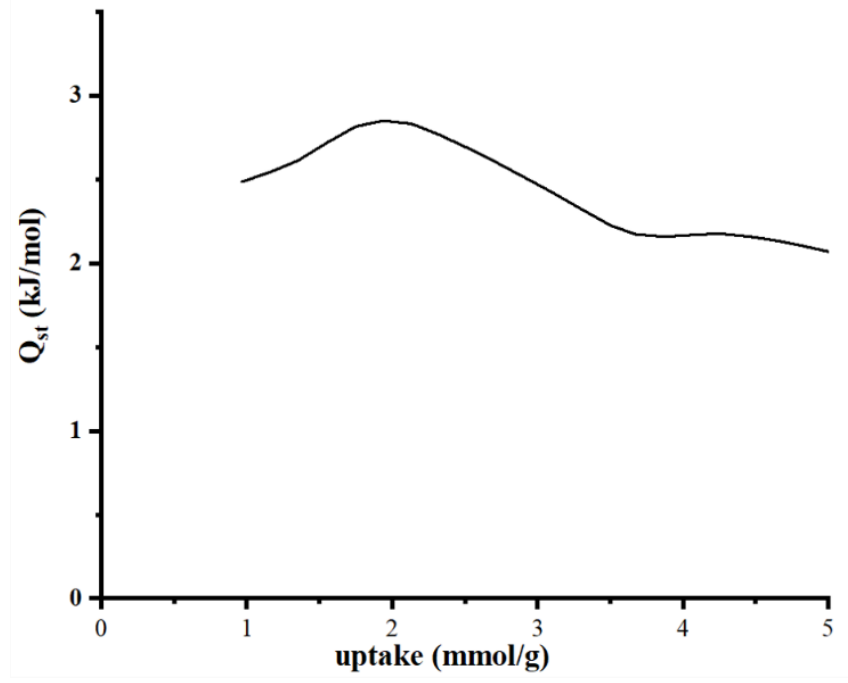

Figure. S30 The isosteric heat of $\mathrm{H}_{2}$ adsorption for AlOC-26-NC estimated by the virial equation. 


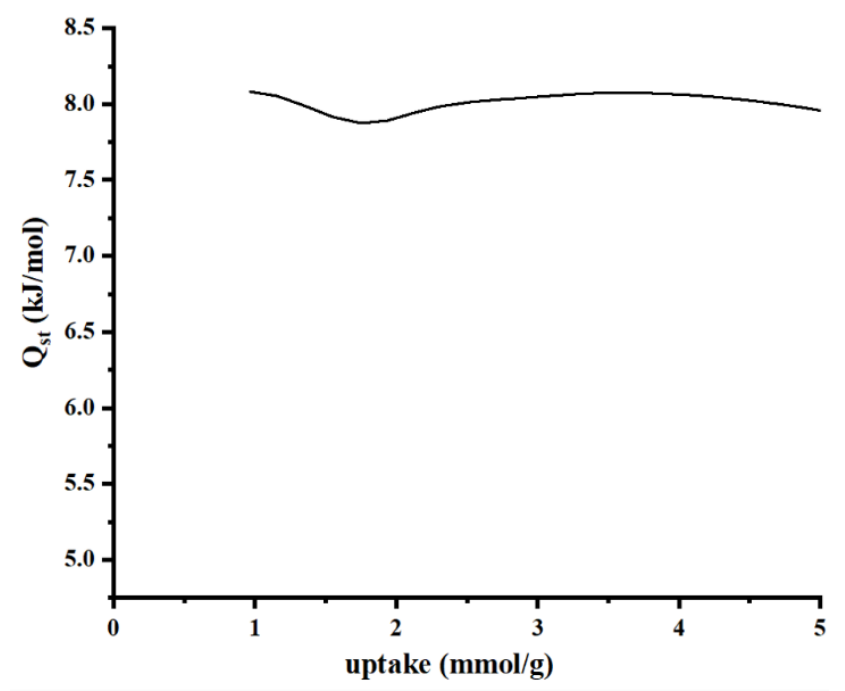

Figure. $\mathrm{S}_{31}$ The isosteric heat of $\mathrm{H}_{2}$ adsorption for AlOC-27-NC estimated by the virial equation.

\section{Massive production}

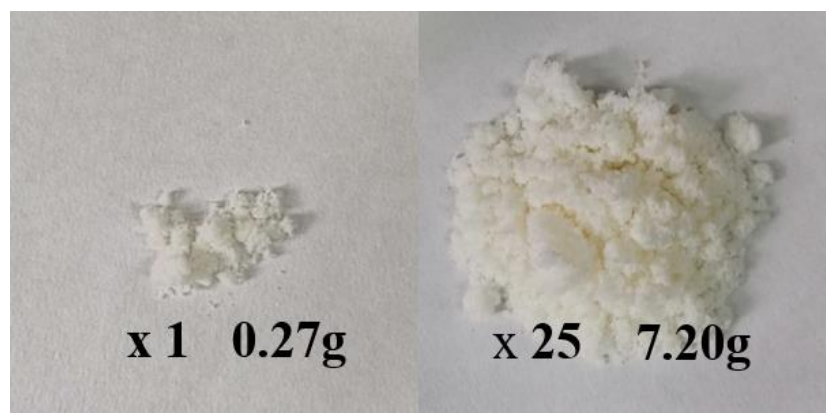

Figure. S32 Massive production of AlOC-27-NC.

\section{Chemical stability tests}

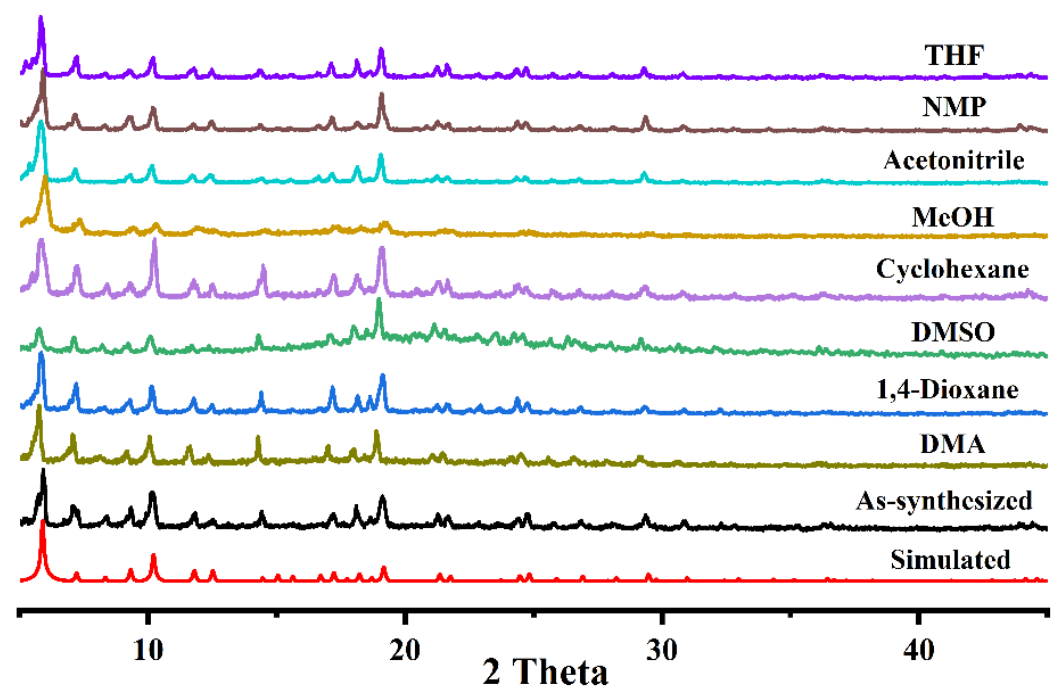

Figure. S33 PXRD patterns of AlOC-26-NC in different organic solvents at room temperature for $24 \mathrm{~h}$. 


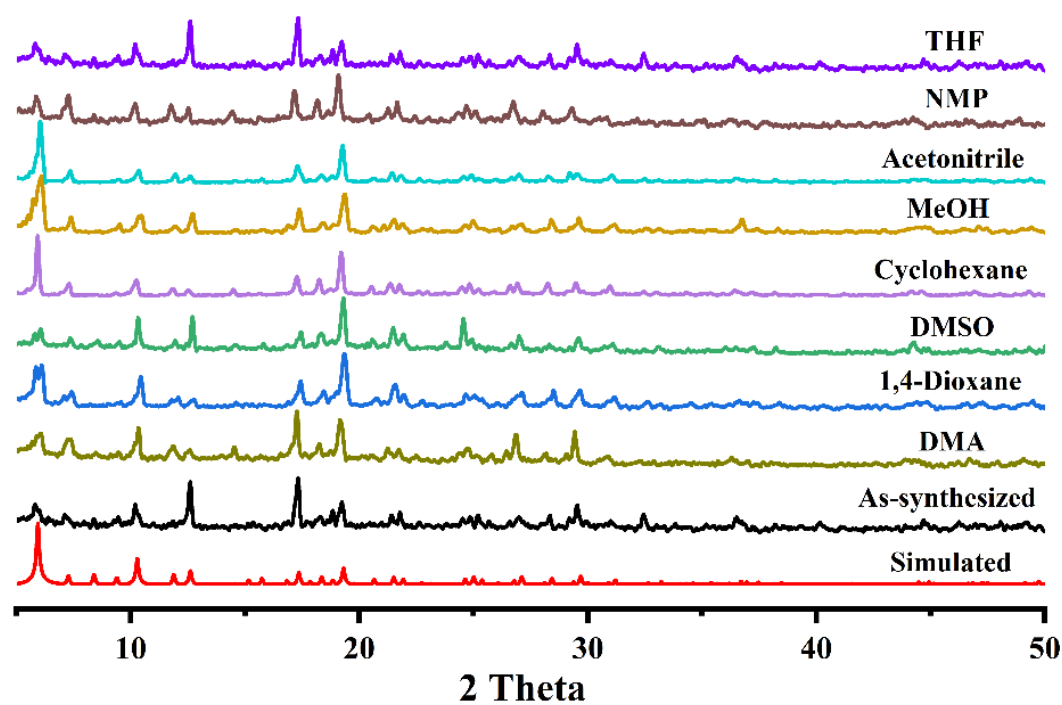

Figure. S34 PXRD patterns of AlOC-27-NC in different organic solvents at room temperature for $24 \mathrm{~h}$.

\section{Iodine vapor adsorption}

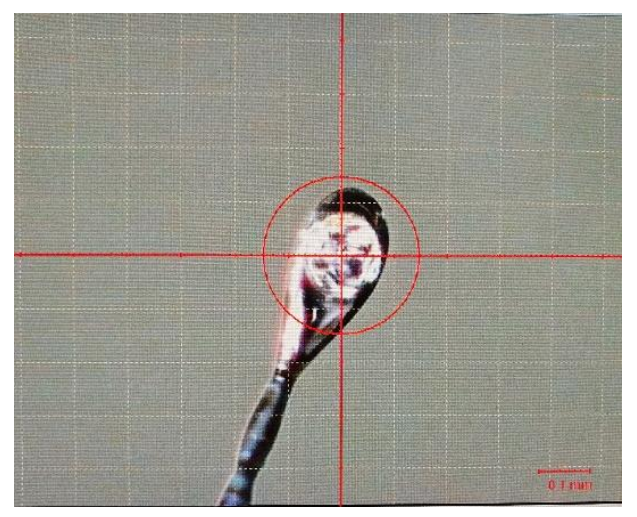

Figure. S35 Measurement photo of crystal of AlOC-27-NC (scale bar o.1 mm) in Rigaku Mini Flex II diffractometer.

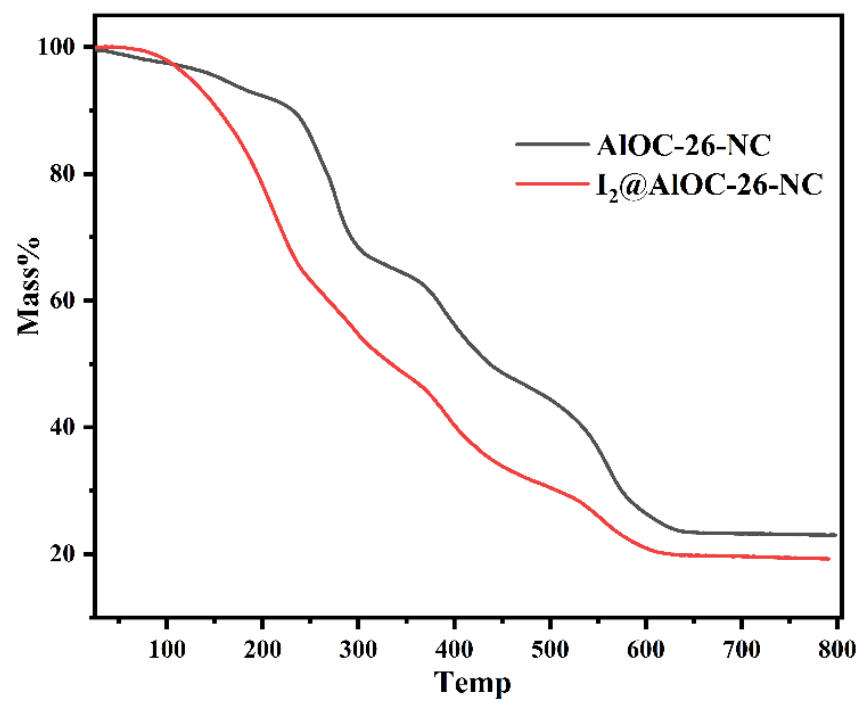

Figure. S36 TGA curves of AlOC-26-NC before and after iodine adsorption. 


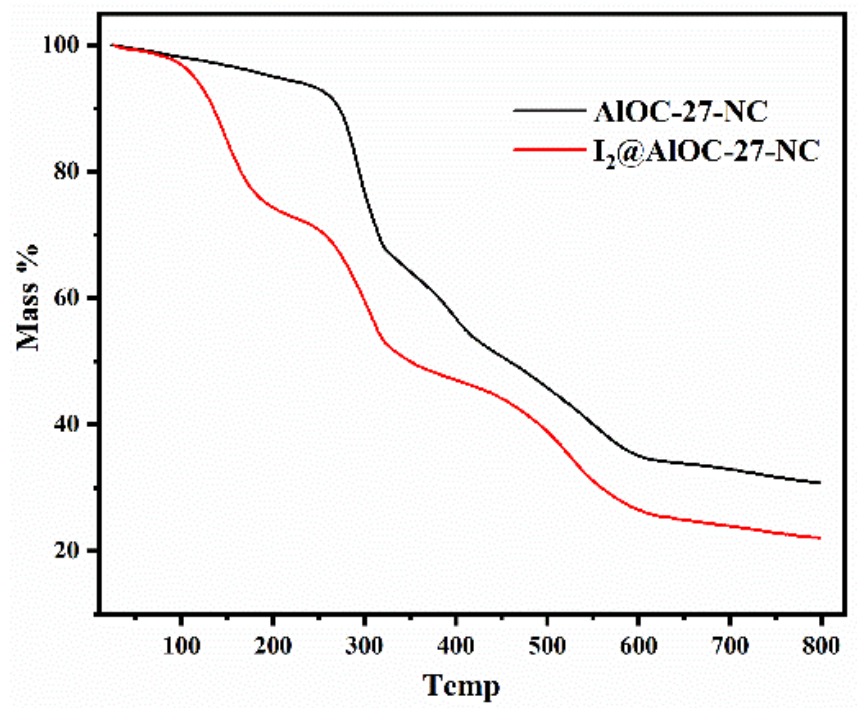

Figure. S37 TGA curves of AlOC-27-NC before and after iodine adsorption.

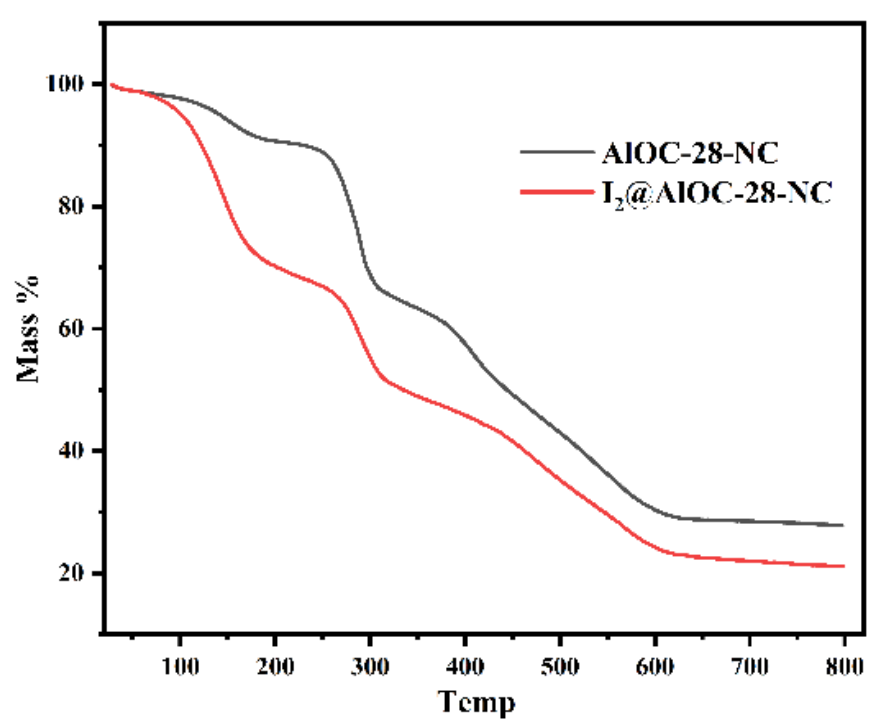

Figure. S38 TGA curves of AlOC-28-NC before and after iodine adsorption.

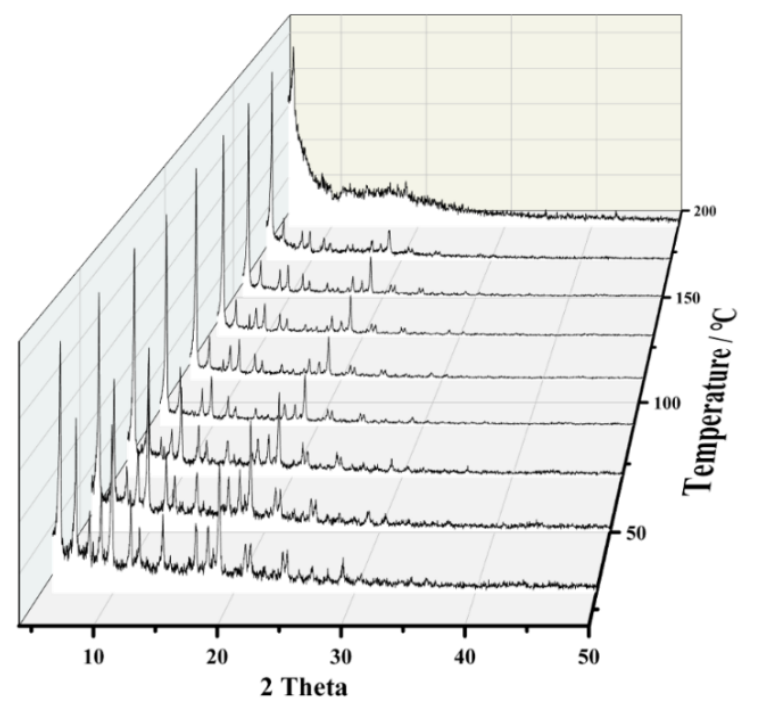

Figure. S39 Temperatures-dependent PXRD patterns of AlOC-27-NC. 


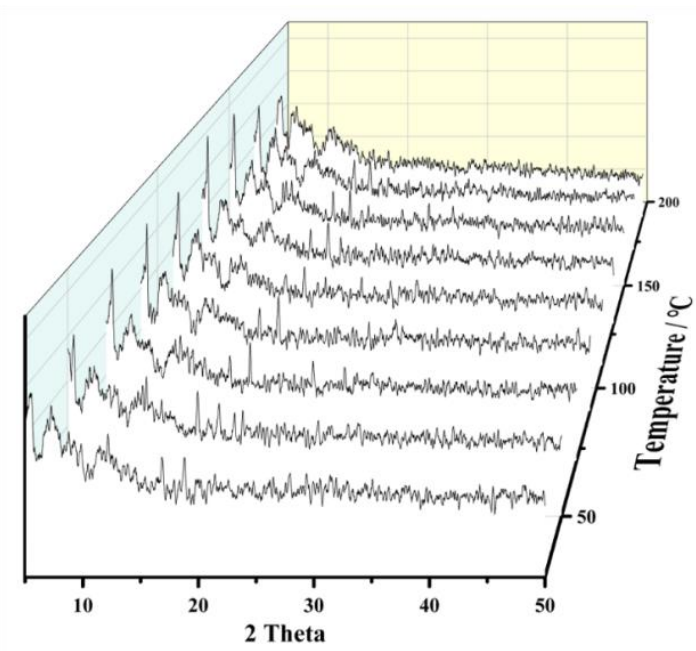

Figure. S40 Temperatures-dependent PXRD patterns of AlOC-28-NC.

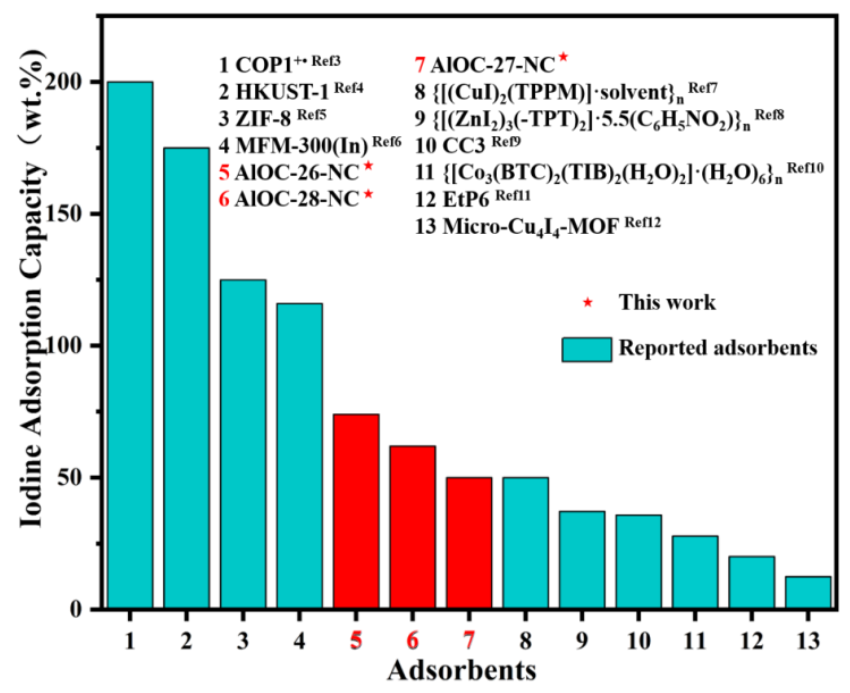

Figure. S41 Iodine adsorption capacities of different solid-state materials. The red numbers represent the AlOC-NCs in this work and the others were previously reported adsorbents.

Table S1 A summary of solid-state materials for the iodine vapour capture

\begin{tabular}{|c|c|c|c|c|c|}
\hline Materials & $\begin{array}{l}\text { BET } \\
\text { surface } \\
\text { area } \\
\left(\mathrm{m}^{2} / \mathrm{g}\right)\end{array}$ & $\begin{array}{l}\text { Iodine } \\
\text { Uptake } \\
(\mathrm{g} / \mathrm{g})\end{array}$ & $\begin{array}{l}\text { Iodine } \\
\text { Uptake } \\
\text { (wt.\%) }\end{array}$ & Test conditions & Ref \\
\hline $\mathrm{COP}^{+}$ & $17 \cdot 9$ & - & 200 & $\begin{array}{l}\text { Vapor adsorption, } \\
70^{\circ} \mathrm{C}, \quad \text { ambient } \\
\text { pressure }\end{array}$ & 3 \\
\hline HKUST-1 & 1850 & 1.75 & 175 & $\begin{array}{l}\text { Vapor adsorption, } \\
75^{\circ} \mathrm{C}, \quad \text { ambient } \\
\text { pressure }\end{array}$ & 4 \\
\hline ZIF-8 & 1630 & 1.25 & 125 & $\begin{array}{l}\text { Vapor adsorption, } \\
350 K, \quad \text { ambient } \\
\text { pressure }\end{array}$ & 5 \\
\hline MFM-300(In) & 1050 & 1.16 & 116 & $\begin{array}{l}\text { Vapor adsorption, } \\
80^{\circ} \mathrm{C}, \quad \text { ambient } \\
\text { pressure }\end{array}$ & 6 \\
\hline $\mathrm{AlOC}-26-\mathrm{NC}$ & 508 & 0.701 & 70.1 & $\begin{array}{l}\text { Vapor adsorption, } \\
80^{\circ} \mathrm{C}, \quad \text { ambient }\end{array}$ & $\begin{array}{l}\text { This } \\
\text { work }\end{array}$ \\
\hline
\end{tabular}




\begin{tabular}{|c|c|c|c|c|c|}
\hline & & & & pressure & \\
\hline $\mathrm{AlOC}-28-\mathrm{NC}$ & _- & 0.621 & 62.1 & $\begin{array}{l}\text { Vapor adsorption, } \\
80^{\circ} \mathrm{C}, \quad \text { ambient } \\
\text { pressure }\end{array}$ & $\begin{array}{l}\text { This } \\
\text { work }\end{array}$ \\
\hline $\mathrm{AlOC}-27-\mathrm{NC}$ & 285 & 0.503 & 50.3 & $\begin{array}{lr}\text { Vapor } & \text { adsorption, } \\
80^{\circ} \mathrm{C}, & \text { ambient } \\
\text { pressure } & \end{array}$ & $\begin{array}{l}\text { This } \\
\text { work }\end{array}$ \\
\hline$\left\{\left[(\mathrm{CuI})_{2}(\mathrm{TPPM})\right] \cdot \text { solvent }\right\}_{\mathrm{n}}$ & - & - & 50 & $\begin{array}{lr}\text { Vapor } & \text { adsorption, } \\
80^{\circ} \mathrm{C}, & \text { ambient } \\
\text { pressure } & \end{array}$ & 7 \\
\hline$\left\{\left[\left(\mathrm{ZnI}_{2}\right)_{3}(-\mathrm{TPT})_{2}\right] \cdot 5 \cdot 5\left(\mathrm{C}_{6} \mathrm{H}_{5} \mathrm{NO}_{2}\right)\right\}_{\mathrm{n}}$ & - & 0.59 & 37.2 & $\begin{array}{lr}\text { Vapor } & \text { adsorption, } \\
80^{\circ} \mathrm{C}, & \text { ambient } \\
\text { pressure } & \end{array}$ & 8 \\
\hline $\mathrm{CC}_{3}$ & 730 & - & 35.8 & $\begin{array}{lr}\text { Vapor } & \text { adsorption, } \\
80^{\circ} \mathrm{C}, & \text { ambient } \\
\text { pressure } & \end{array}$ & 9 \\
\hline$\left\{\left[\mathrm{Co}_{3}(\mathrm{BTC})_{2}(\mathrm{TIB})_{2}\left(\mathrm{H}_{2} \mathrm{O}\right)_{2}\right] \cdot\left(\mathrm{H}_{2} \mathrm{O}\right)_{6}\right\}_{\mathrm{n}}$ & - & - & 27.9 & $\begin{array}{lr}\text { Vapor } & \text { adsorption, } \\
80^{\circ} \mathrm{C}, & \text { ambient } \\
\text { pressure } & \end{array}$ & 10 \\
\hline EtP6 & - & 0.25 & 20.1 & $\begin{array}{lr}\text { Vapor } & \text { adsorption, } \\
60^{\circ} \mathrm{C}, & \text { ambient } \\
\text { pressure } & \end{array}$ & 11 \\
\hline Micro- $\mathrm{Cu}_{4} \mathrm{I}_{4}$-MOF & 641 & 0.13 & 12.5 & $\begin{array}{l}\text { Vapor adsorption, } \\
\text { room temperature, } \\
\text { ambient pressure }\end{array}$ & 12 \\
\hline
\end{tabular}

\section{Reference:}

3. Skorjanc, T.; Shetty, D.; Sharma, S. K.; Raya, J.; Traboulsi, H.; Han, D. S.; Lalla, J.; Newlon, R.; Jagannathan, R.; Kirmizialtin, S.; Olsen, J. C.; Trabolsi, A., Redox-Responsive Covalent Organic Nanosheets from Viologens and Calix[4]arene for Iodine and Toxic Dye Capture. Chem. Eur. J. 2018, 24 (34), 8648-8655.

4. Sava, D. F.; Chapman, K. W.; Rodriguez, M. A.; Greathouse, J. A.; Crozier, P. S.; Zhao, H.; Chupas, P. J.; Nenoff, T. M., Competitive $\mathrm{I}_{2}$ Sorption by Cu-BTC from Humid Gas Streams. Chem. Mater. 2013, 25 (13), 2591-2596.

5. Sava, D. F.; Rodriguez, M. A.; Chapman, K. W.; Chupas, P. J.; Greathouse, J. A.; Crozier, P. S.; Nenoff, T. M., Capture of volatile iodine, a gaseous fission product, by zeolitic imidazolate framework-8. J. Am. Chem. Soc. 2011, 133 (32), 12398-401.

6. Zhang, X.; da Silva, I.; Godfrey, H. G. W.; Callear, S. K.; Sapchenko, S. A.; Cheng, Y.; Vitorica-Yrezabal, I.; Frogley, M. D.; Cinque, G.; Tang, C. C.; Giacobbe, C.; Dejoie, C.; Rudic, S.; Ramirez-Cuesta, A. J.; Denecke, M. A.; Yang, S.; Schroder, M., Confinement of Iodine Molecules into Triple-Helical Chains within Robust Metal-Organic Frameworks. J. Am. Chem. Soc. 2017, 139 (45), 16289-16296.

7. Kitagawa, H.; Ohtsu, H.; Kawano, M., Kinetic assembly of a thermally stable porous coordination network based on labile $\mathrm{CuI}$ units and the visualization of I2 sorption. Angew. Chem. Int. Ed. 2013, 52 (47), 12395-9.

8. Brunet, G.; Safin, D. A.; Aghaji, M. Z.; Robeyns, K.; Korobkov, I.; Woo, T. K.; Murugesu, M., Stepwise crystallographic visualization of dynamic guest binding in a nanoporous framework. Chem. Sci. 2017, 8 (4), 3171-3177.

9. Hasell, T.; Schmidtmann, M.; Cooper, A. I., Molecular doping of porous organic cages. J. Am. Chem. Soc. 2011, 133 (38), 14920-3.

10. Rachuri, Y.; Bisht, K. K.; Suresh, E., Two-Dimensional Coordination Polymers Comprising Mixed Tripodal Ligands for Selective Colorimetric Detection of Water and Iodine Capture. Cryst. Growth Des. 2014, 14 (7), 3300-3308.

11. Jie, K.; Zhou, Y.; Li, E.; Li, Z.; Zhao, R.; Huang, F., Reversible Iodine Capture by Nonporous Pillar[6]arene Crystals. J. Am. Chem. Soc. 2017, 139 (43), 15320-15323.

12. Zhu, N. X.; Zhao, C. W.; Wang, J. C.; Li, Y. A.; Dong, Y. B., Micro-Cu $\mathrm{C}_{4} \mathrm{I}_{4}-\mathrm{MOF}$ : reversible 
iodine adsorption and catalytic properties for tandem reaction of Friedel-Crafts alkylation of indoles with acetals. Chem. Commun. 2016, 52 (86), 12702-12705.
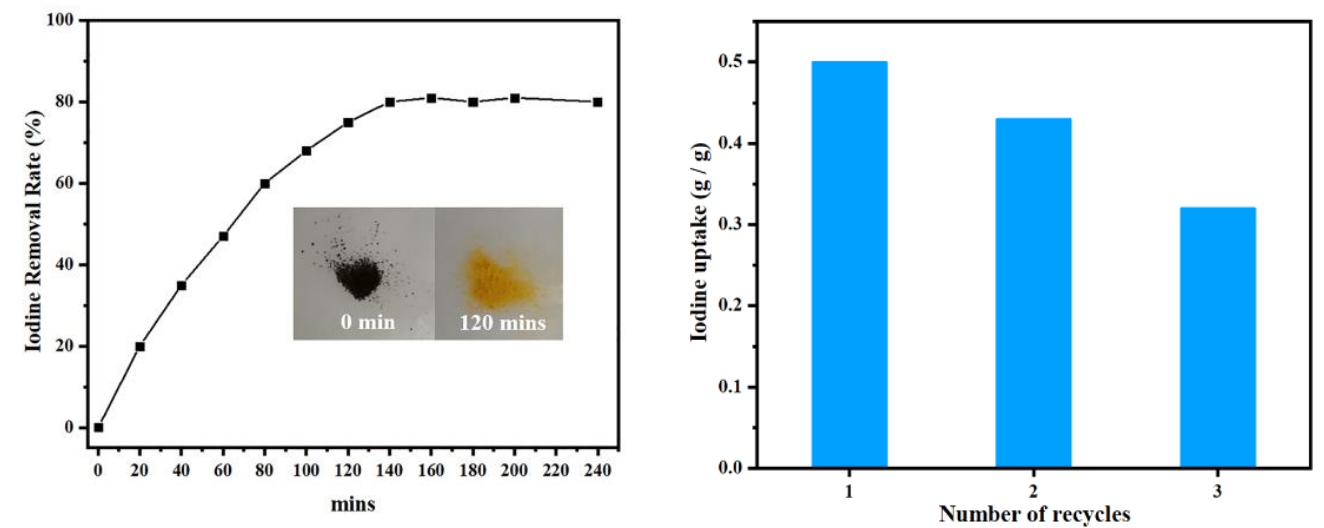

Figure. S42 Iodine vapor adsorption cycle experiment of AlOC-27-NC.

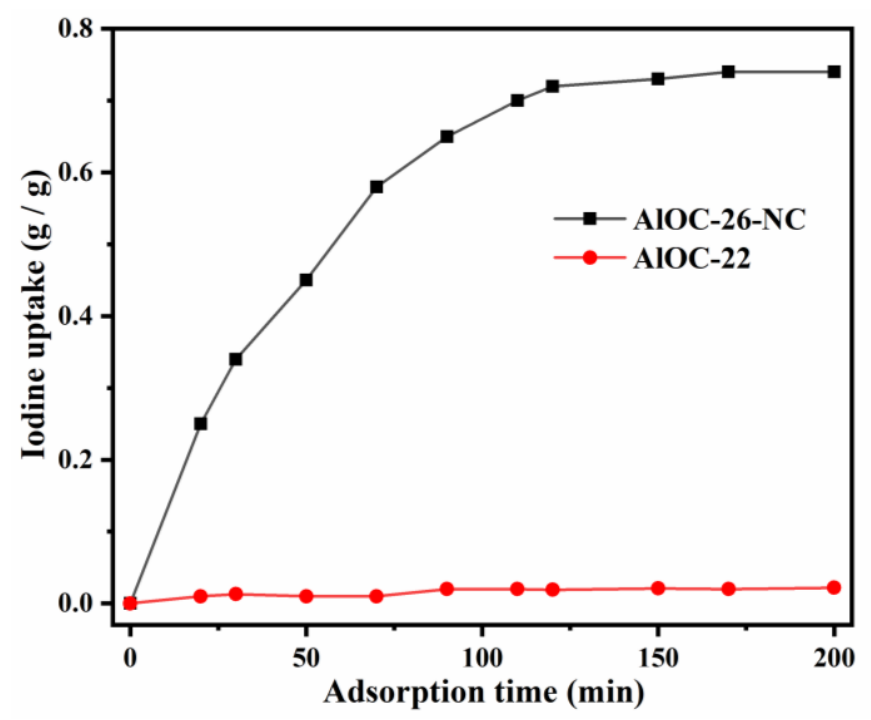

Figure. $\mathrm{S}_{43}$ Amount of $\mathrm{I}_{2}$ adsorption in isomers AlOC-26-NC and AlOC-22 as a function of time.

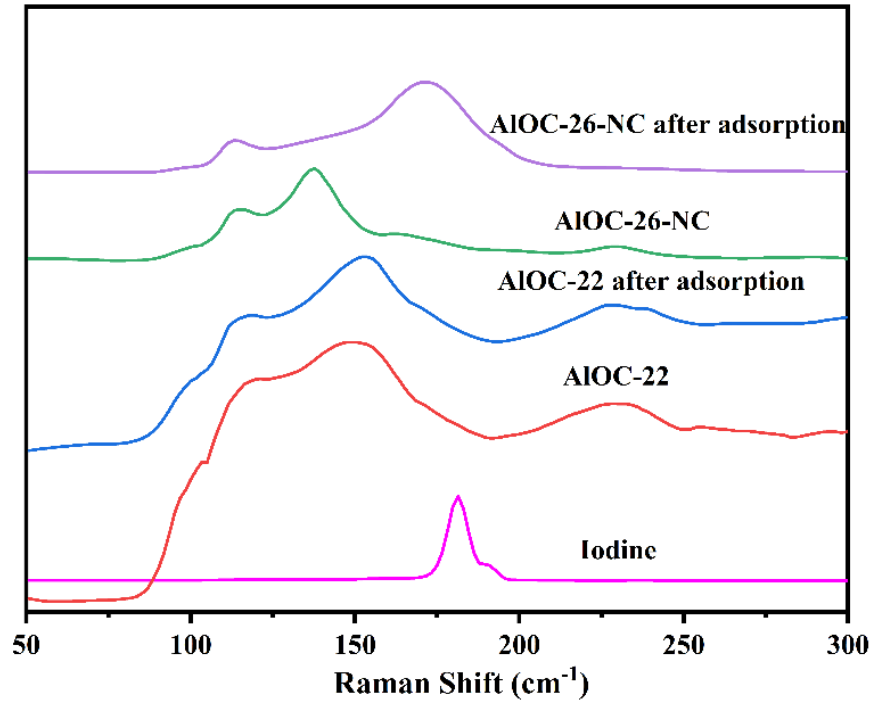

Figure. S44 Comparison of Raman spectra of AlOC-26-NC, AlOC-22 before and after iodine adsorption, and solid $\mathrm{I}_{2}$ in the low energy region. 


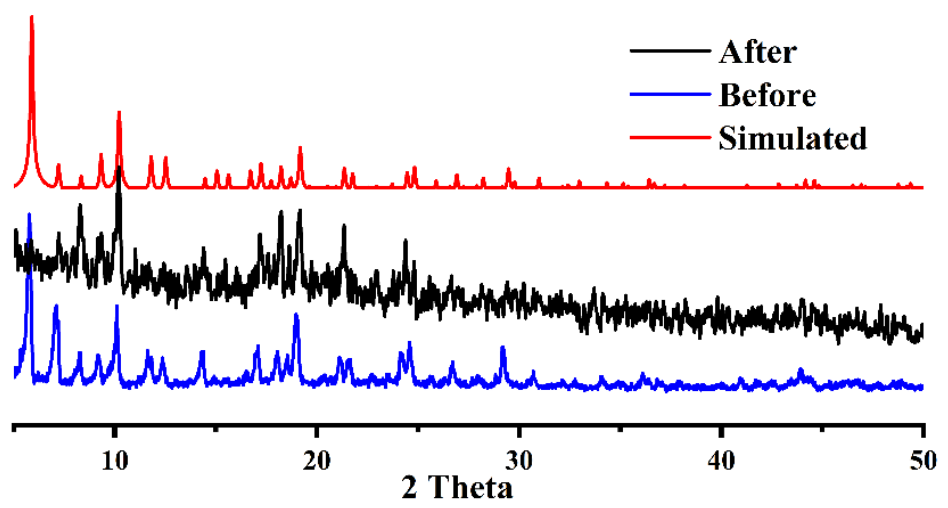

Figure. S45 PXRD patterns of AlOC-26-NC before and after iodine adsorption.

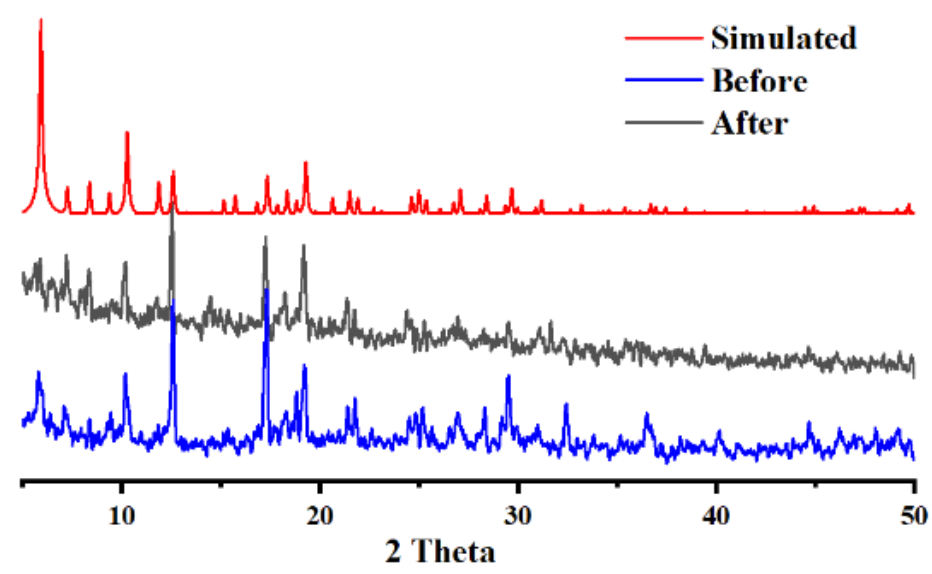

Figure. S46 PXRD patterns of AlOC-27-NC before and after iodine adsorption.

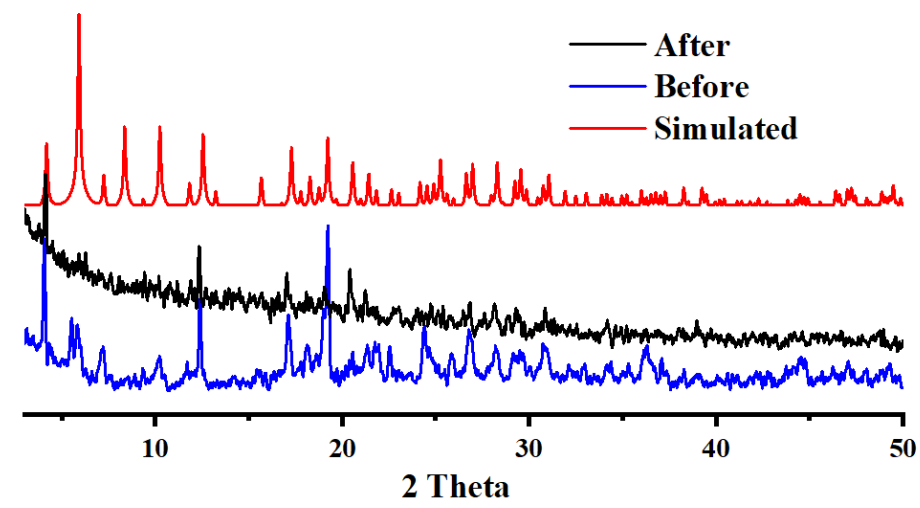

Figure. S47 PXRD patterns of AlOC-28-NC before and after iodine adsorption. 

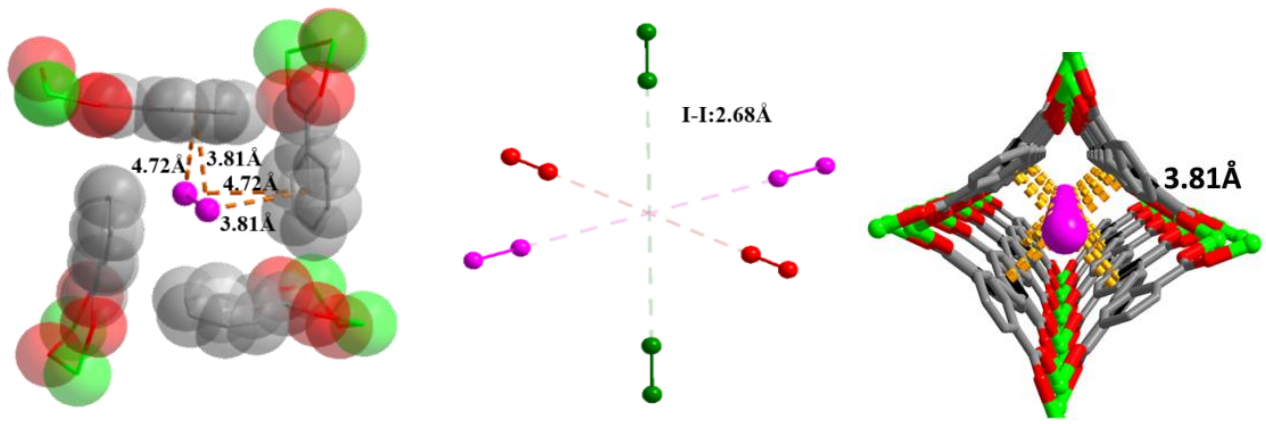

Figure $\mathrm{S}_{4} 8 \mathrm{I} \cdots \pi$ interaction (left) and views of the linear chains of $\mathrm{I}_{2}$ molecules inside AlOC-27-NC and AlOC-28-NC (right).

\section{EDS-mapping spectras}

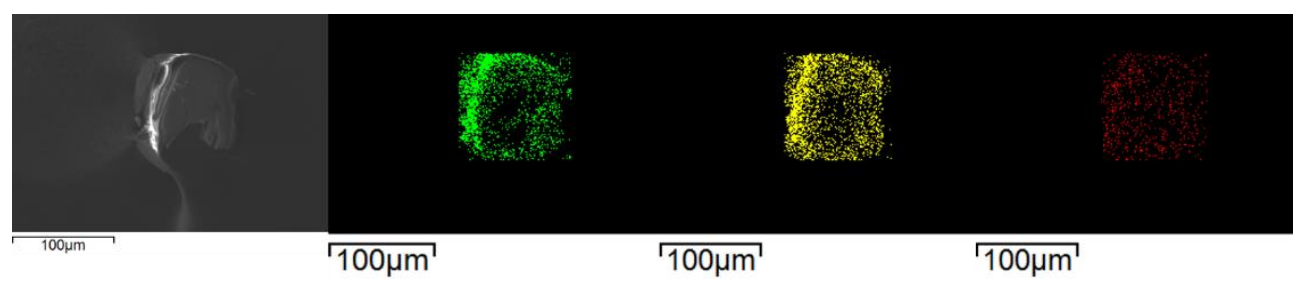

Figure. S49 EDS-mapping spectra of $\mathrm{I}_{2} @ A l O C-27-\mathrm{NC}$. From left to right are crystal appearance, aluminum, chlorine and iodine elements.

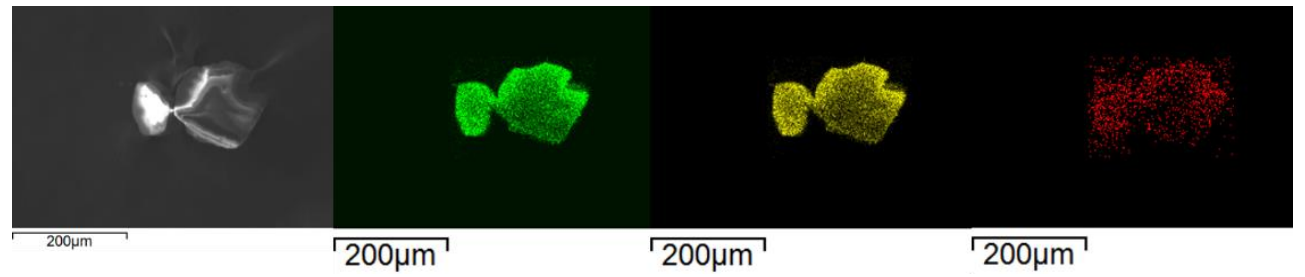

Figure. S5o EDS-mapping spectra of $\mathrm{I}_{2} @ A l O C-28-N C$. From left to right are crystal appearance, aluminum, bromine and iodine elements. 


\section{FT-IR spectra of molecular rings}

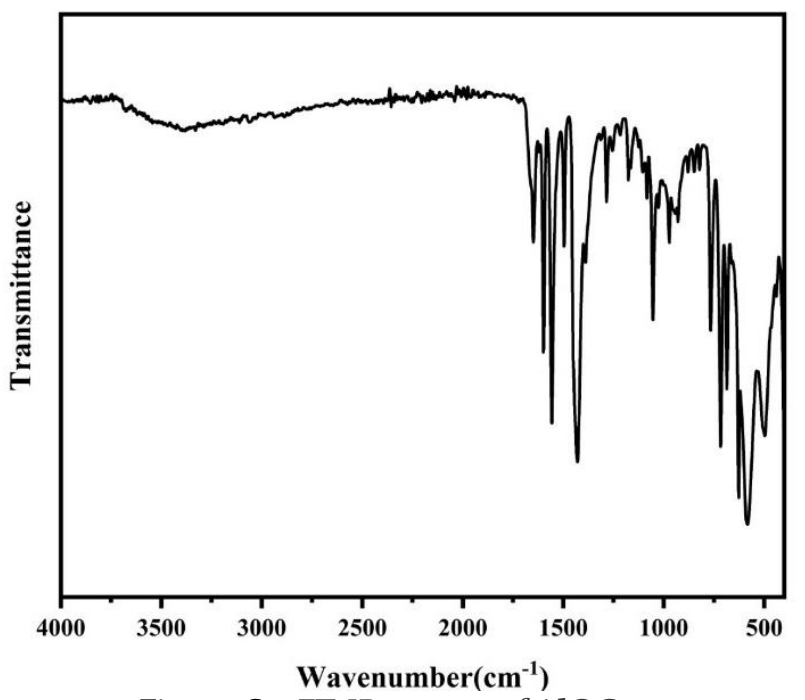

Figure. S51 FT-IR spectra of AlOC-15.

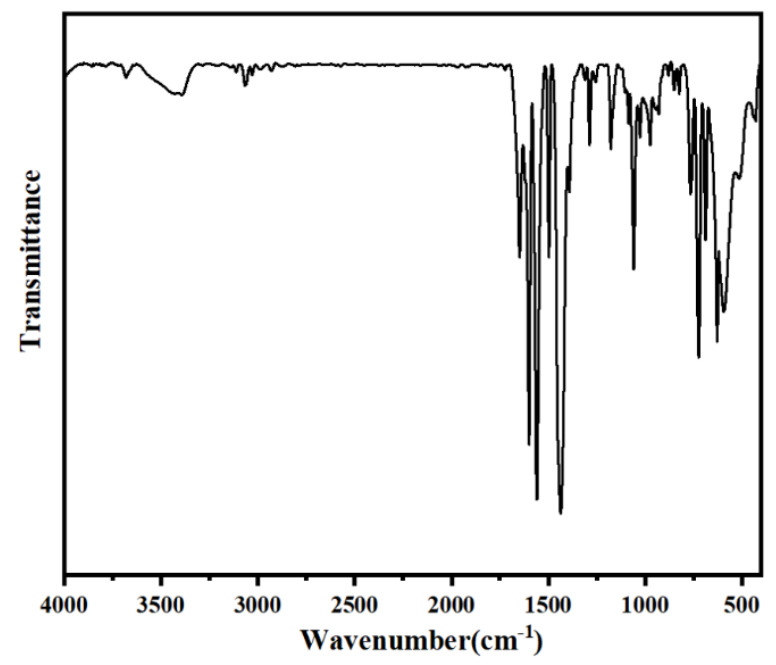

Figure. S52 FT-IR spectra of AlOC-16.

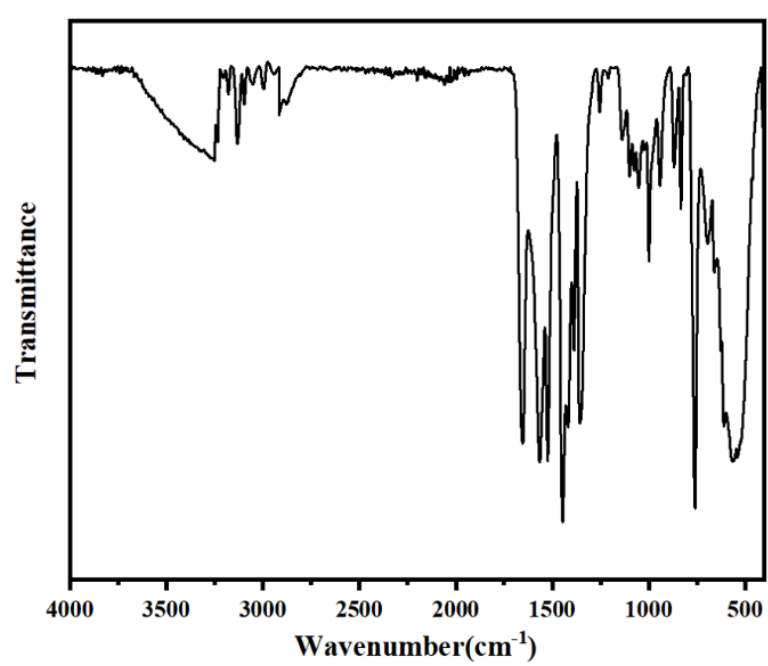

Figure. S53 FT-IR spectra of AlOC-17. 


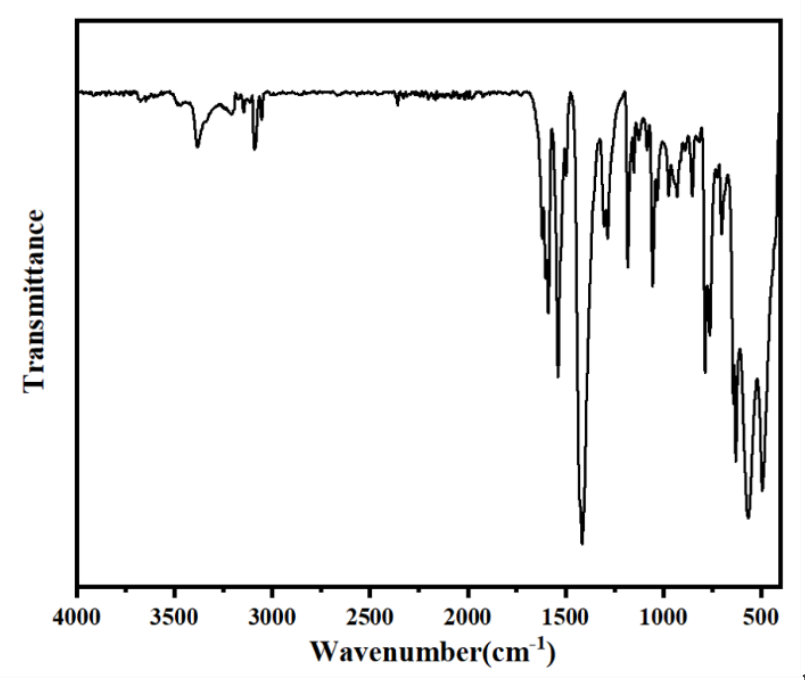

Figure. S54 FT-IR spectra of AlOC-18.

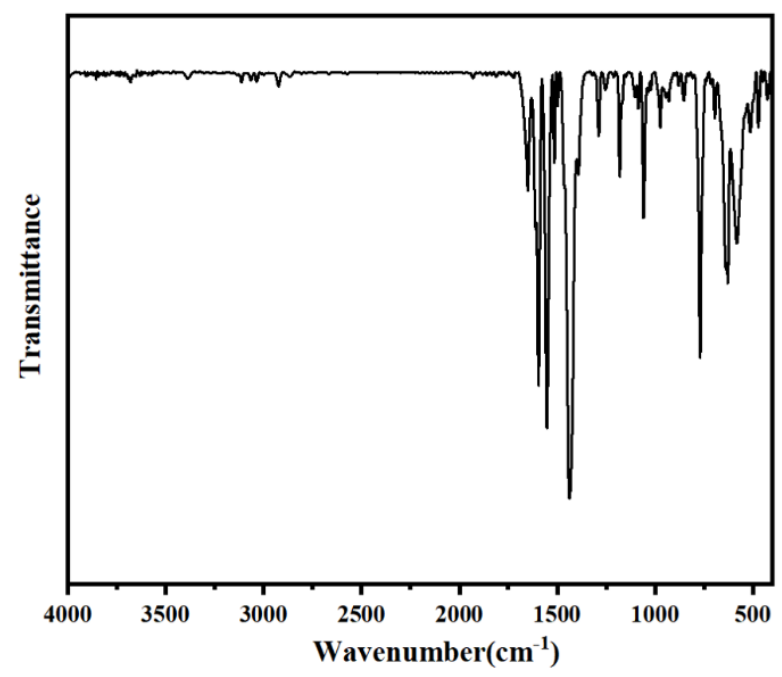

Figure. S55 FT-IR spectra of AlOC-19.

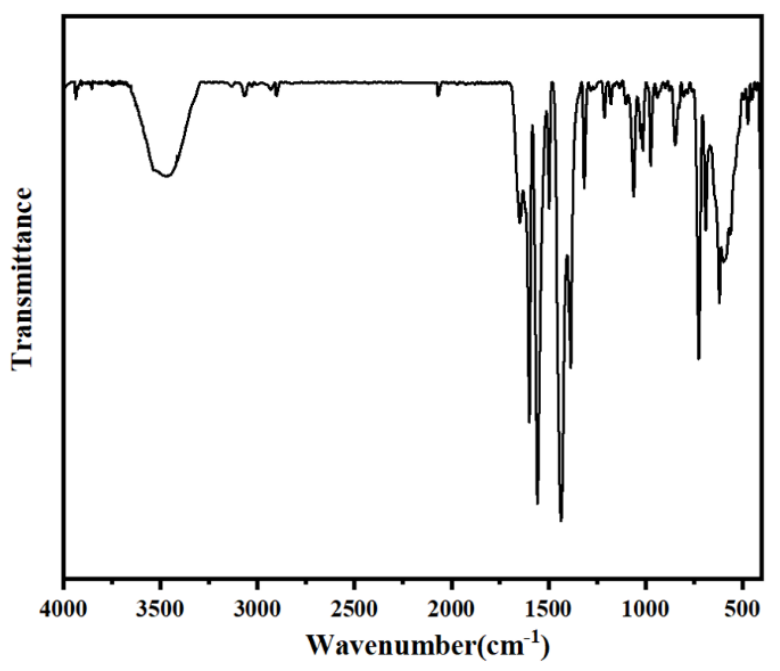

Figure. S56 FT-IR spectra of AlOC-2o. 


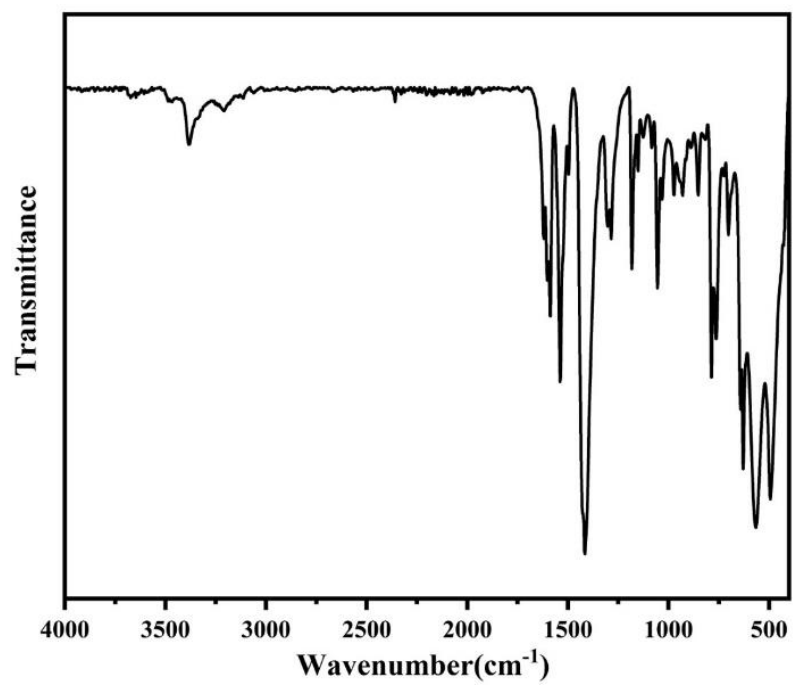

Figure. S57 FT-IR spectra of AlOC-21.

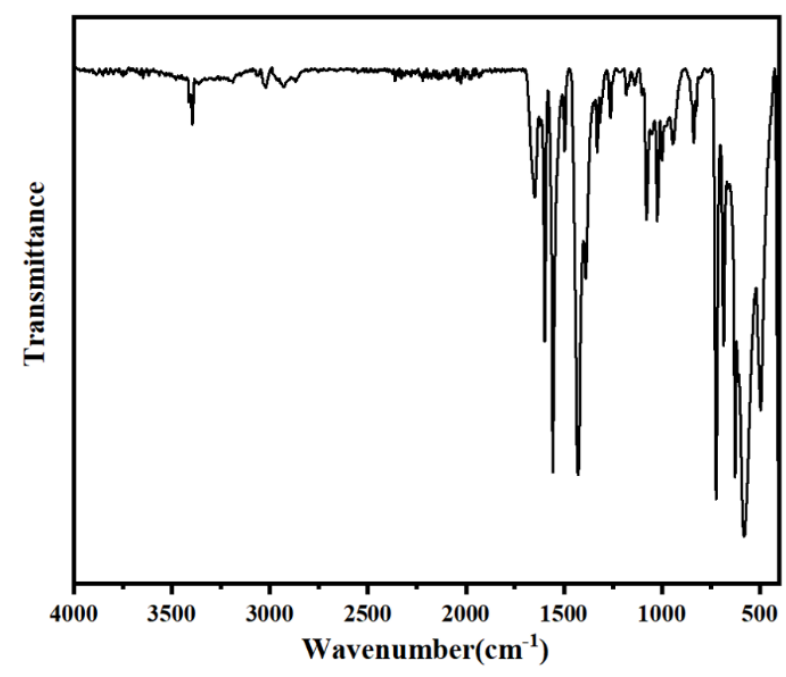

Figure. S58 FT-IR spectra of AlOC-22.

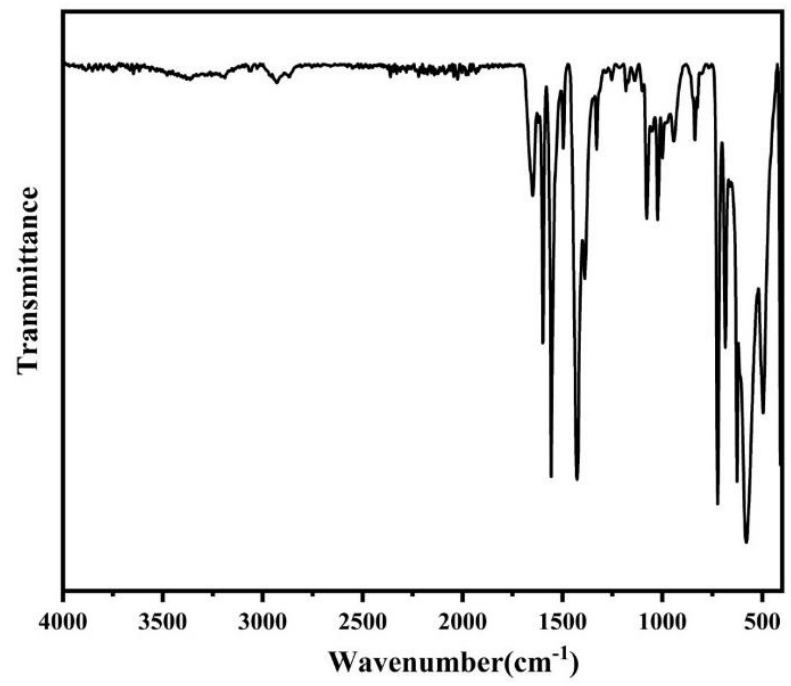

Figure. S59 FT-IR spectra of AlOC-23. 


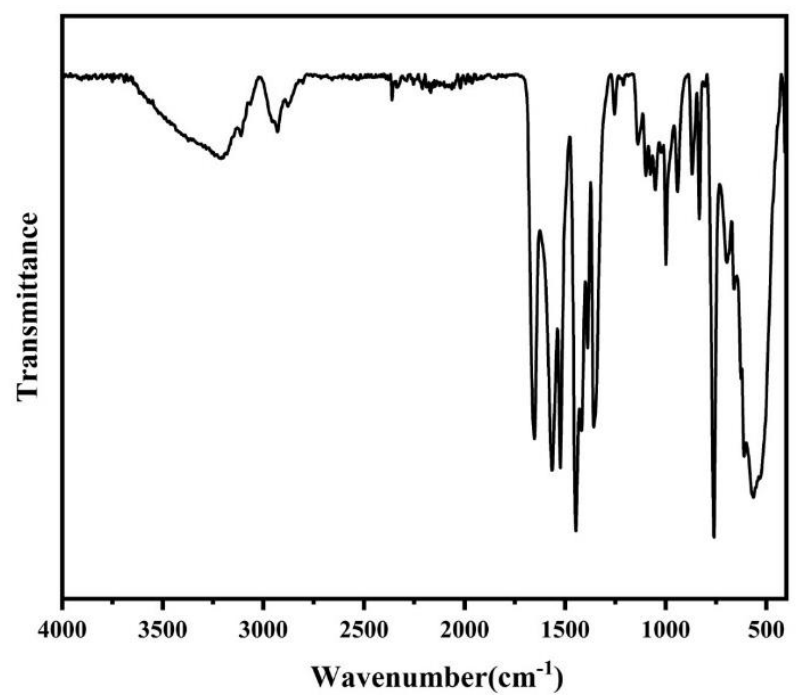

Figure. S6o FT-IR spectra of AlOC-24.

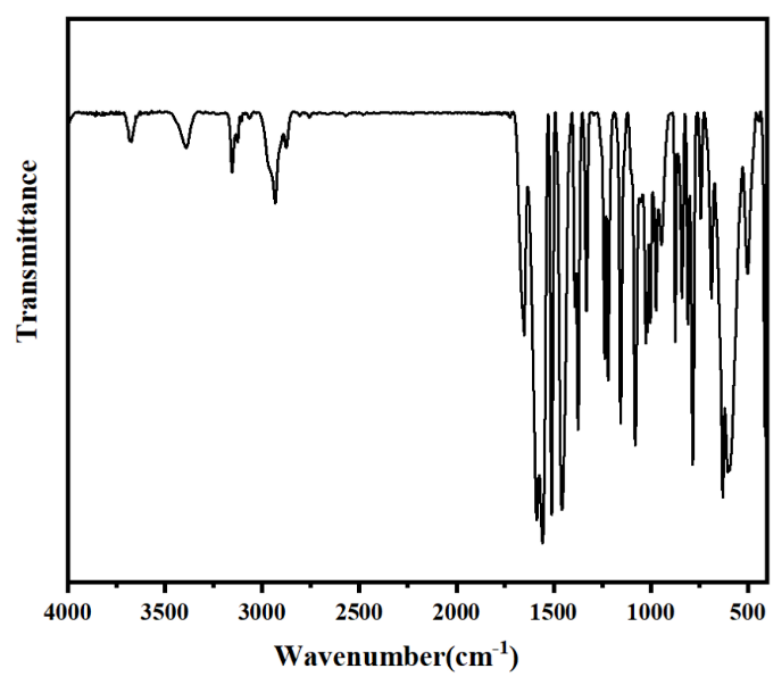

Figure. S61 FT-IR spectra of AlOC-25.

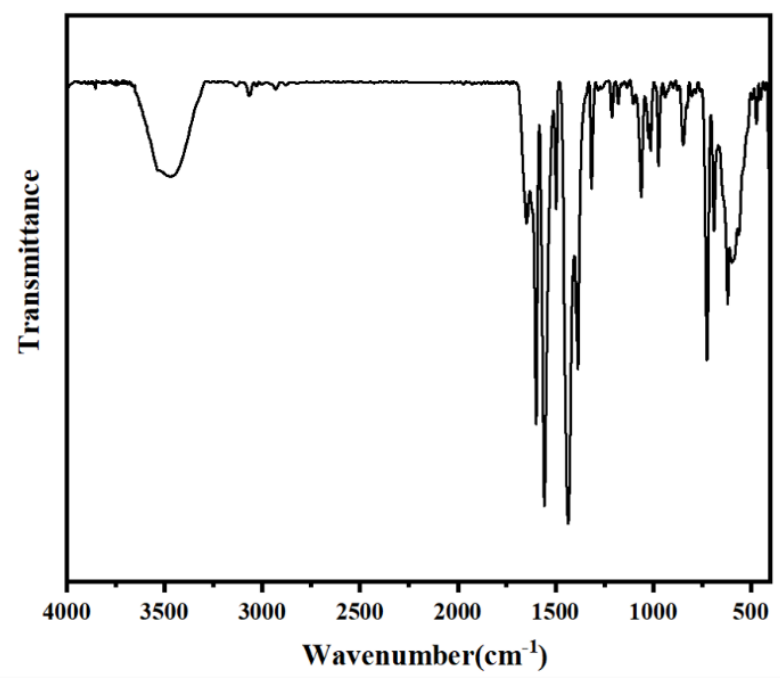

Figure. S62 FT-IR spectra of AlOC-26-NC. 


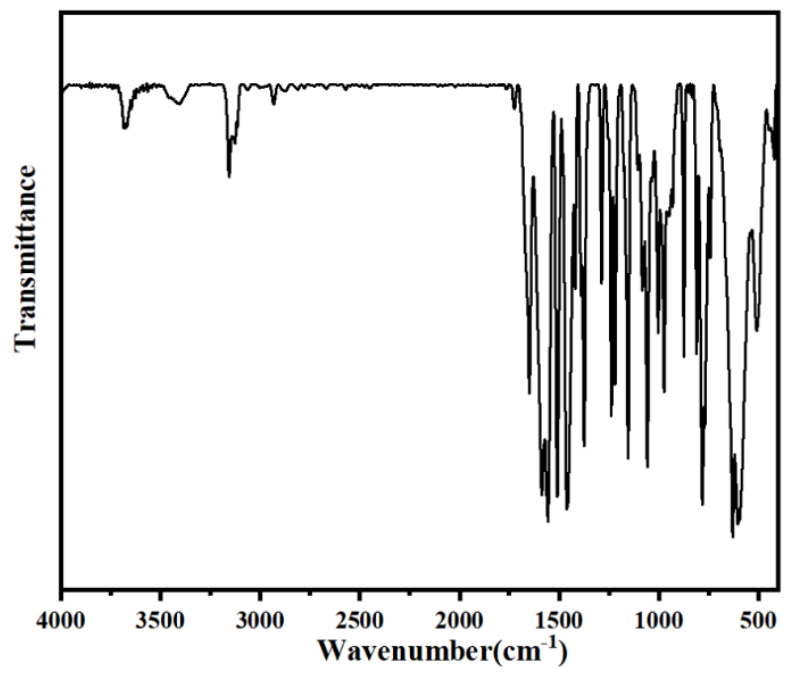

Figure. S63 FT-IR spectra of AlOC-27-NC.

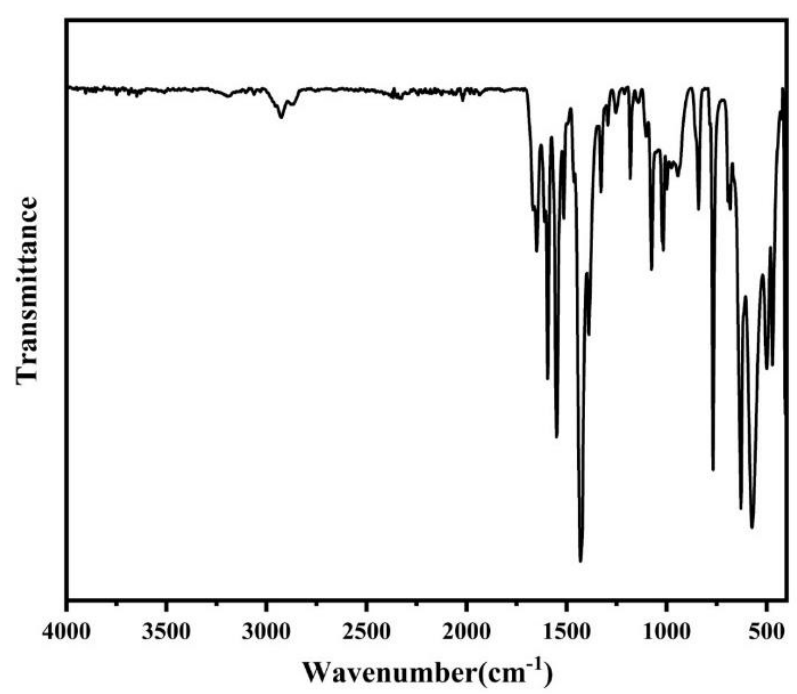

Figure. S64 FT-IR spectra of AlOC-28-NC.

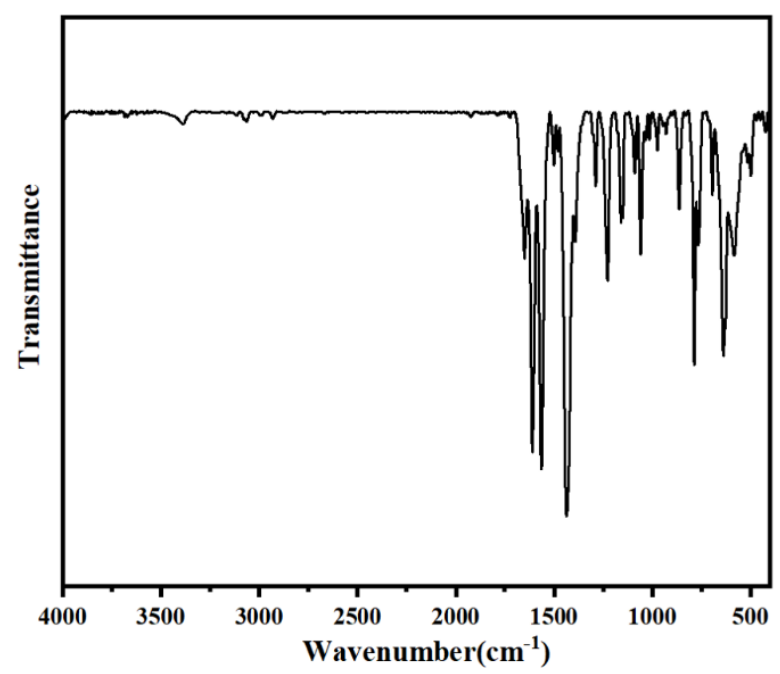

Figure. S65 FT-IR spectra of AlOC-29-NC. 


\section{PXRD analyses for molecular rings}

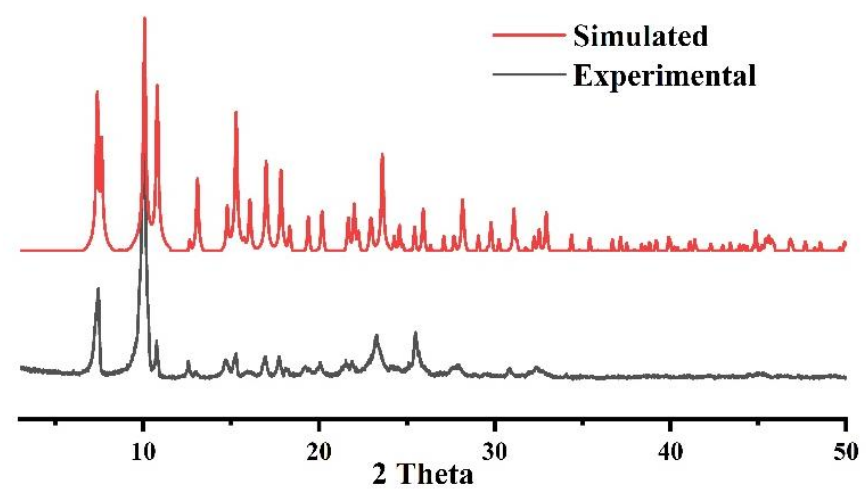

Figure. S66 PXRD analyses for AlOC-15.

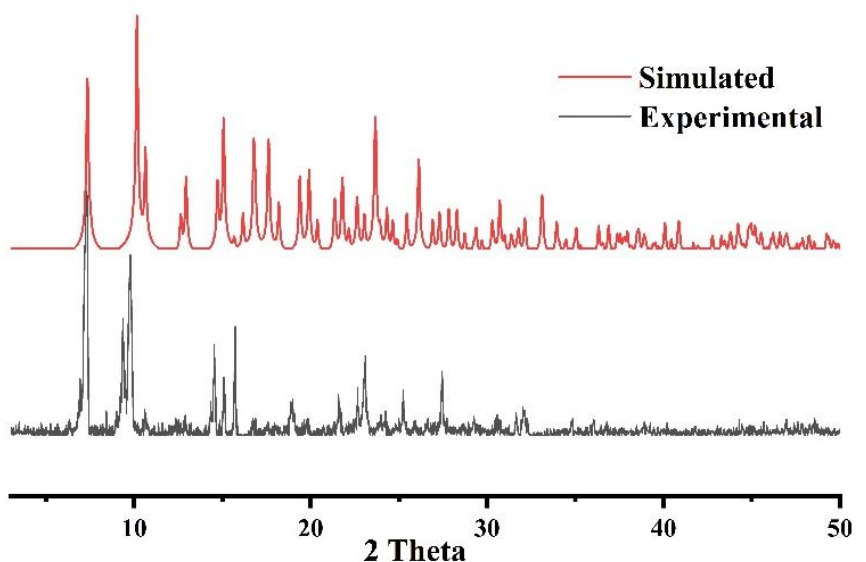

Figure. S67 PXRD analyses for AlOC-16.

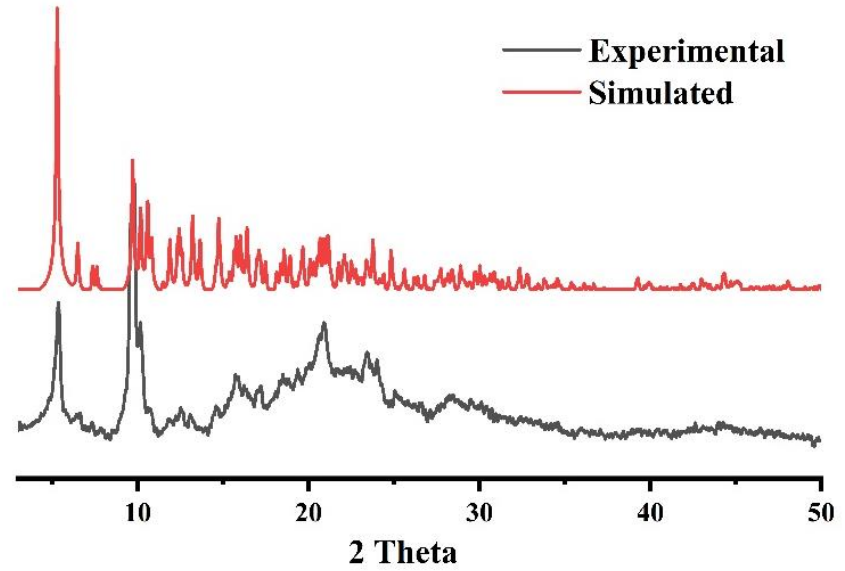

Figure. S68 PXRD analyses for AlOC-17. 


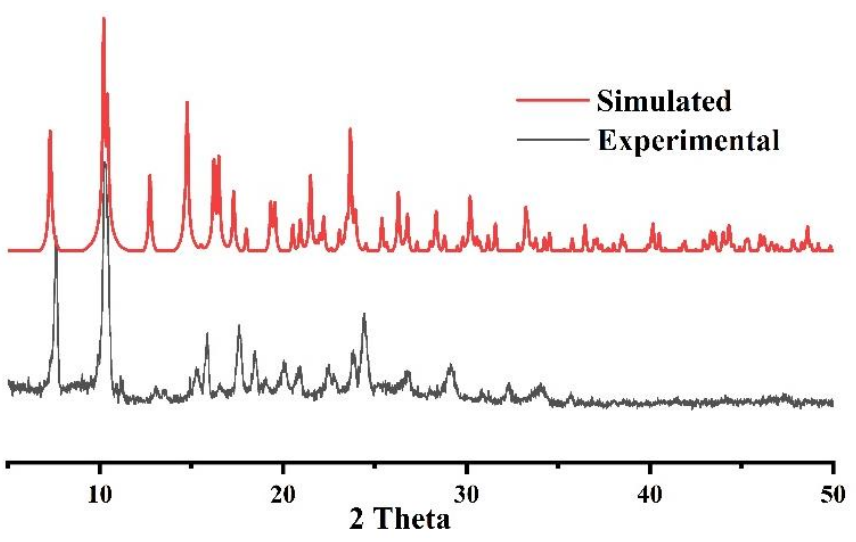

Figure. S69 PXRD analyses for AlOC-18.

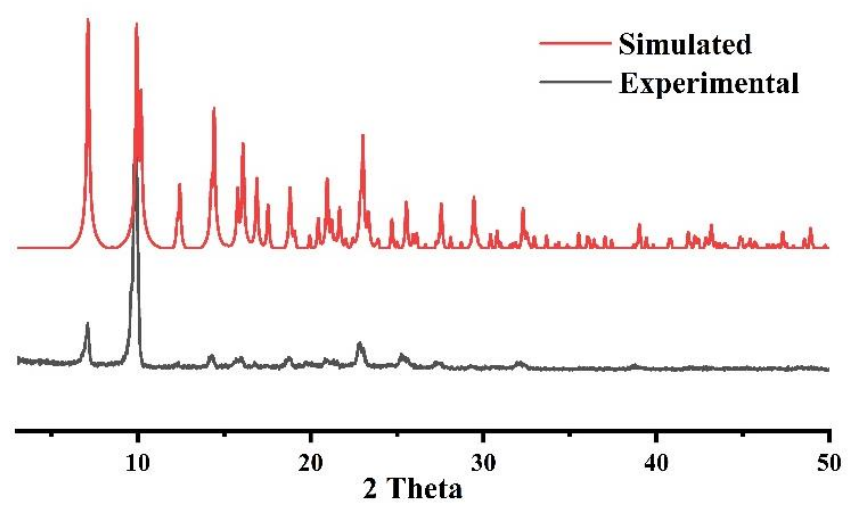

Figure. S7o PXRD analyses for AlOC-19.

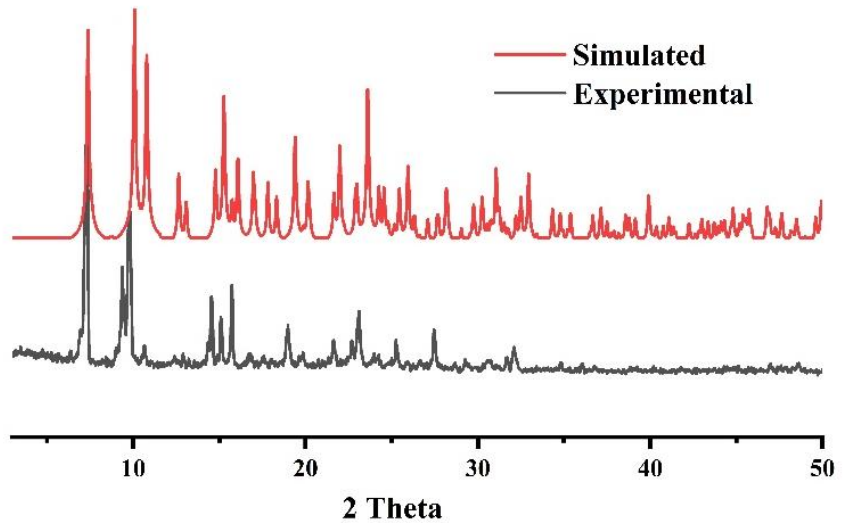

Figure. S71 PXRD analyses for AlOC-2o. 


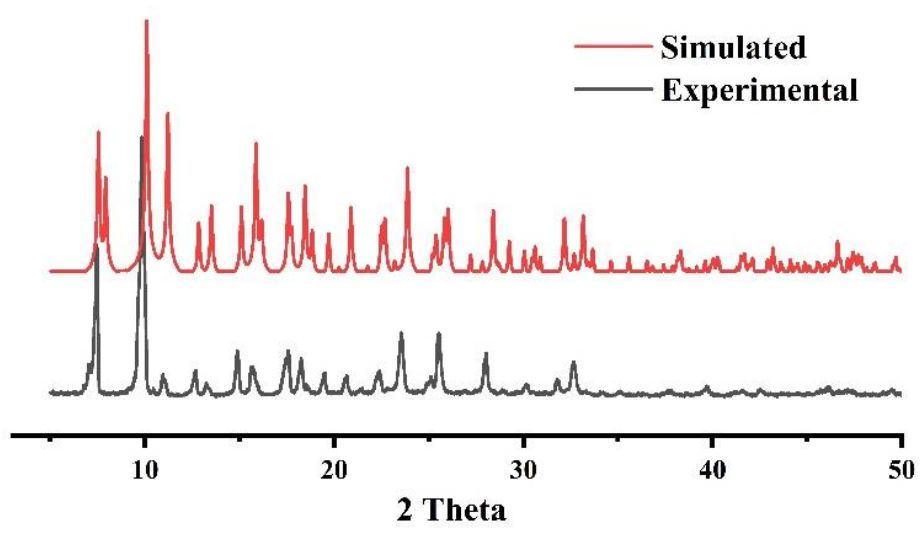

Figure. S72 PXRD analyses for AlOC-21.

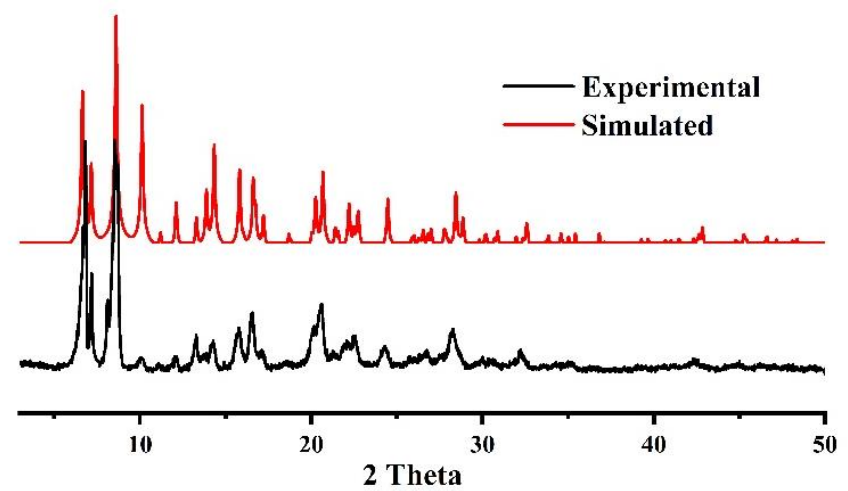

Figure. S73 PXRD analyses for AlOC-23.

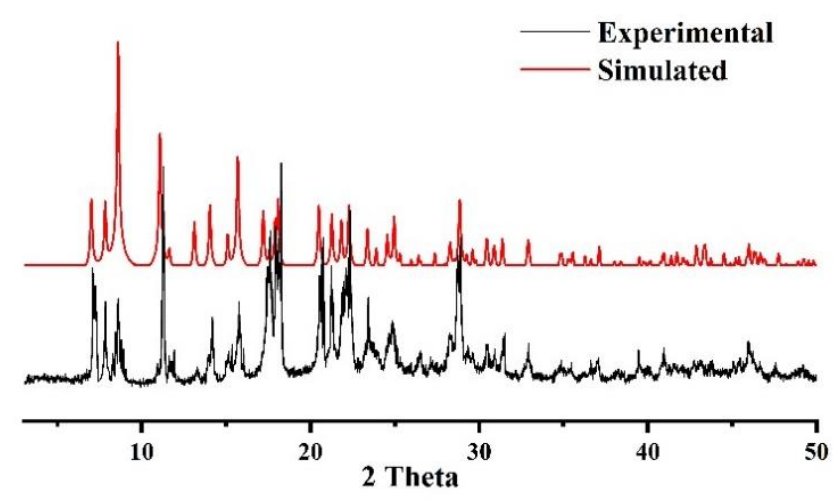

Figure. S74 PXRD analyses for AlOC-24. 


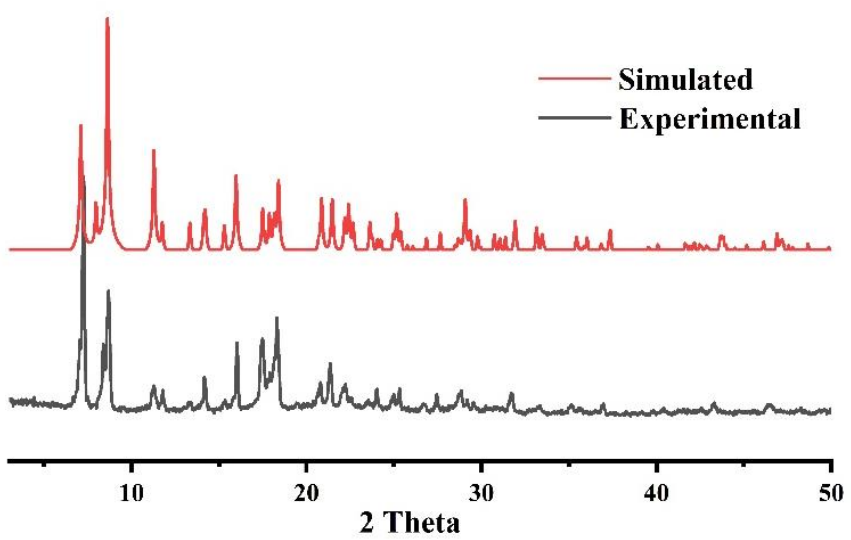

Figure. S75 PXRD analyses for AlOC-25.

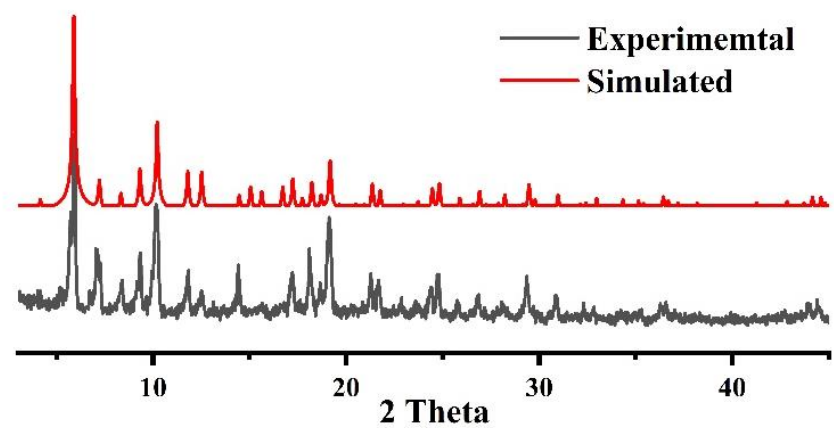

Figure. S76 PXRD analyses for AlOC-26-NC.

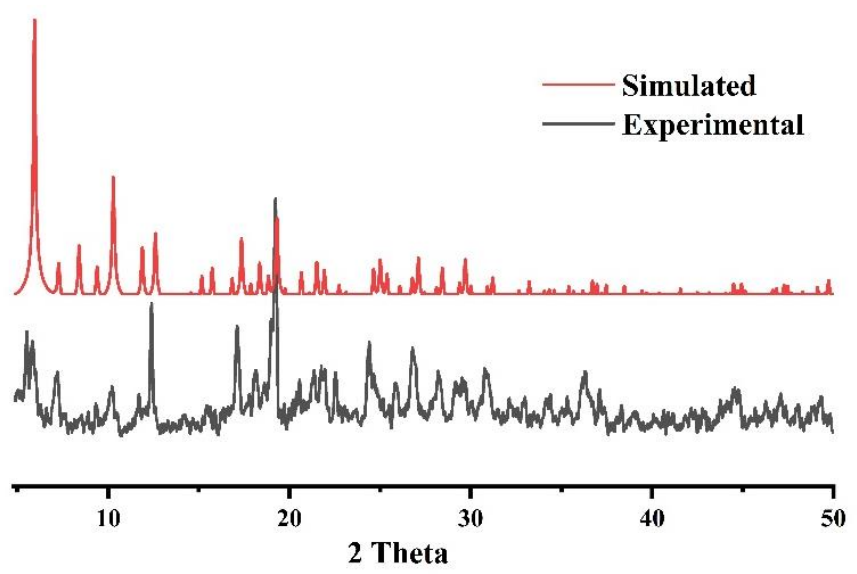

Figure. S77 PXRD analyses for AlOC-27-NC. 


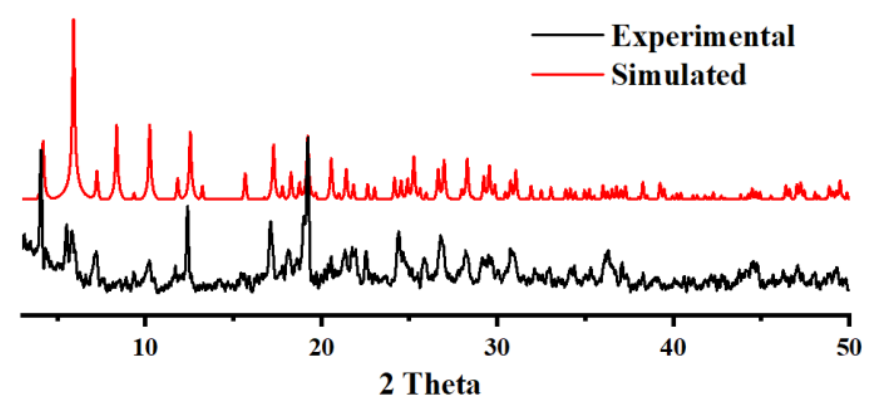

Figure. S78 PXRD analyses for AlOC-28-NC.

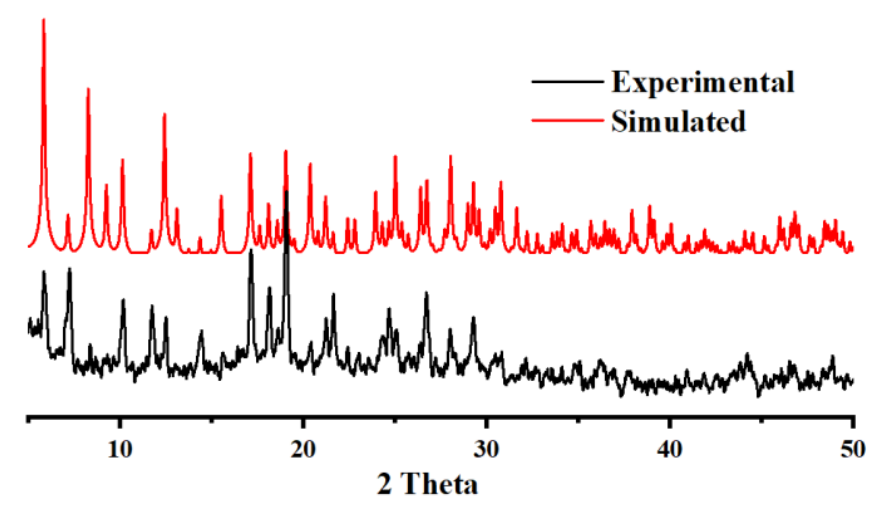

Figure. S79 PXRD analyses for AlOC-29-NC. 
17. Crystallography data for molecular rings

Table S2 Crystallographic data of AlOC-15 to AlOC-18

\begin{tabular}{|c|c|c|c|c|}
\hline & AlOC-15 & AlOC-16 & AlOC-17 & AlOC-18 \\
\hline Empirical formula & $\mathrm{C}_{80} \mathrm{H}_{64} \mathrm{Al}_{8} \mathrm{~N}_{16} \mathrm{O}_{24}$ & $\mathrm{C}_{80} \mathrm{H}_{72} \mathrm{Al}_{8} \mathrm{~N}_{24} \mathrm{O}_{24}$ & $\mathrm{C}_{86} \mathrm{H}_{80} \mathrm{Al}_{8} \mathrm{~N}_{28} \mathrm{O}_{24}$ & $\mathrm{C}_{80} \mathrm{H}_{90} \mathrm{Al}_{8} \mathrm{~N}_{32} \mathrm{O}_{25}$ \\
\hline Formula weight & $1849 \cdot 31$ & 1969.45 & 2105.62 & 2115.68 \\
\hline Temperature / K & $150.00(10)$ & $100.7(7)$ & $100.0(8)$ & $100.00(16)$ \\
\hline Crystal system & tetragonal & tetragonal & monoclinic & tetragonal \\
\hline Space group & $P_{4} / \mathrm{nnc}$ & $P_{4} /$ nnc & $C_{2} / \mathrm{c}$ & $P_{4} /$ nnc \\
\hline$a[\AA]$ & $16.3859(7)$ & $14.6074(3)$ & $24.897(2)$ & $16.9487(4)$ \\
\hline$b[\AA]$ & $16.3859(7)$ & $15 \cdot 3320(3)$ & $23.222(2)$ & $16.9487(4)$ \\
\hline$c[\AA]$ & $17 \cdot 561(2)$ & $17 \cdot 4104(10)$ & $18.880(2)$ & $17.2887(8)$ \\
\hline$\alpha\left[^{\circ}\right]$ & 90 & 90 & 90 & 90 \\
\hline$\beta\left[^{\circ}\right]$ & 90 & 90 & $105.230(10)$ & 90 \\
\hline$\gamma\left[^{\circ}\right]$ & 90 & 90 & 90 & 90 \\
\hline$V\left[\AA^{3}\right]$ & $4715.1(7)$ & $4807 \cdot 7(4)$ & $10532.4(19)$ & $4966.3(3)$ \\
\hline$Z$ & 2 & 2 & 4 & 2 \\
\hline$\rho_{\text {calcd }}\left[\mathrm{g} \mathrm{cm}^{-3}\right]$ & 1.303 & 1.360 & 1.328 & 1.415 \\
\hline$\mu\left[\mathrm{mm}^{-1}\right]$ & 1.487 & 0.973 & 0.918 & 1.536 \\
\hline$F($ ooo $)$ & 1904.0 & 2032.0 & 4352.0 & 2196.0 \\
\hline \multirow{3}{*}{ Index ranges } & $-9 \leq h \leq 18$ & $-16 \leq h \leq 19$ & $-27 \leq h \leq 28$ & $-18 \leq h \leq 19$ \\
\hline & $-14 \leq \mathrm{k} \leq 15$ & $-19 \leq \mathrm{k} \leq 19$ & $-26 \leq \mathrm{k} \leq 25$ & $-17 \leq \mathrm{k} \leq 19$ \\
\hline & $-16 \leq 1 \leq 19$ & $-19 \leq 1 \leq 20$ & $-20 \leq 1 \leq 21$ & $-20 \leq 1 \leq 13$ \\
\hline Reflections collected & 6946 & 12174 & 23221 & 8946 \\
\hline Independent refs $\left[\mathrm{R}_{\mathrm{int}}\right]$ & $1813[0.0621]$ & $2068[0.0470]$ & $8214[0.1046]$ & $2154[0.0496]$ \\
\hline data/restraints/parameters & $1813 / 0 / 146$ & $2068 / 0 / 158$ & $8214 / 52 / 669$ & $2154 / 2 / 171$ \\
\hline Goodness-of-fit on $F^{2}$ & 1.037 & 1.085 & 1.281 & 1.077 \\
\hline$R_{1}, \mathrm{w} R_{2}[I>2 \sigma(I)]$ & $0.0928,0.2489$ & $0.0817,0.2053$ & $0.1362,0.3527$ & $0.0784,0.2517$ \\
\hline$R_{1}, \mathrm{w} R_{2}$ [all data] & $0.1508,0.3101$ & $0.1044,0.2207$ & $0.1929,0.3849$ & $0.1038,0.2887$ \\
\hline
\end{tabular}

Table S 3 Crystallographic data of AlOC-19 to AlOC-22

\begin{tabular}{lllll}
\hline & AlOC-19 & AlOC-20 & AlOC-21 & AlOC-22 \\
\hline Empirical formula & $\mathrm{C}_{88} \mathrm{H}_{88} \mathrm{Al}_{8} \mathrm{~N}_{16} \mathrm{O}_{24}$ & $\mathrm{C}_{80} \mathrm{H}_{82} \mathrm{Al}_{8} \mathrm{~F}_{8} \mathrm{~N}_{16} \mathrm{O}_{27}$ & $\mathrm{C}_{64} \mathrm{H}_{56} \mathrm{Al}_{8} \mathrm{~N}_{16} \mathrm{O}_{32}$ & $\mathrm{C}_{88} \mathrm{H}_{80} \mathrm{Al}_{8} \mathrm{~N}_{16} \mathrm{O}_{26}$ \\
Formula weight & 1969.58 & 2067.45 & 1777.08 & $1993 \cdot 52$ \\
Temperature / K & $110.41(13)$ & $110.29(10)$ & $100.00(12)$ & $293(2)$ \\
Crystal system & tetragonal & tetragonal & tetragonal & tetragonal \\
Space group & $P 4 / \mathrm{nnc}$ & $P_{4} / \mathrm{nnc}$ & $P_{4} / \mathrm{nnc}$ & $P_{4} / \mathrm{nnc}$ \\
$a[\AA]$ & $17.3670(4)$ & $16.4035(2)$ & $15.7992(5)$ & $16.3895(2)$ \\
$b[\AA]$ & $17.3670(4)$ & $16.4035(2)$ & $15.7992(5)$ & $16.3895(2)$ \\
$c\left[^{\AA}\right]$ & $17.7935(7)$ & $17.5487(3)$ & $17.5325(10)$ & $20.4961(5)$ \\
$\alpha\left[^{\circ}\right]$ & 90 & 90 & 90 & 90 \\
$\beta\left[^{\circ}\right]$ & 90 & 90 & 90 & 90 \\
$\gamma\left[^{\circ}\right]$ & 90 & 90 & 90 & 90
\end{tabular}




\begin{tabular}{lllll}
$V\left[\AA^{3}\right]$ & $5366.7(3)$ & $4721.91(14)$ & $4376.4(4)$ & $5505 \cdot 57(19)$ \\
$Z$ & 2 & 2 & 2 & 2 \\
$\rho_{\text {calcd }}\left[\mathrm{g} \mathrm{cm}^{-3}\right]$ & 1.219 & 1.454 & 1.349 & 1.203 \\
$\mu\left[\mathrm{mm}^{-1}\right]$ & 0.856 & 1.086 & 1.647 & 0.849 \\
$F(\mathrm{ooo})$ & 2048.0 & 2132.0 & 1824.0 & 2064.0 \\
& $-22 \leq \mathrm{h} \leq 16$ & $-21 \leq \mathrm{h} \leq 20$ & $-19 \leq \mathrm{h} \leq 4$ & $-21 \leq \mathrm{h} \leq 18$ \\
Index ranges & $-22 \leq \mathrm{k} \leq 21$ & $-20 \leq \mathrm{k} \leq 15$ & $-17 \leq \mathrm{k} \leq 17$ & $-19 \leq \mathrm{k} \leq 10$ \\
& $-22 \leq 1 \leq 14$ & $-20 \leq 1 \leq 22$ & $-21 \leq 1 \leq 16$ & $-26 \leq 1 \leq 22$ \\
Reflections collected & 20070 & 17827 & 8957 & 18937 \\
Independent refs $\left[\mathrm{R}_{\text {int }}\right]$ & $3056[0.0307]$ & $2685[0.0255]$ & $2175[0.0534]$ & $3111[0.0603]$ \\
data/restraints/parameters & $3056 / \mathrm{o} / 157$ & $2685 / 9 / 178$ & $2175 / 7 / 141$ & $3111 / \mathrm{o} / 160$ \\
Goodness-of-fit on $F^{2}$ & 1.034 & 1.135 & 1.095 & 0.871 \\
$R_{1}, \mathrm{w} R_{2}[I>2 \sigma(I)]$ & $0.0687,0.2445$ & $0.0680,0.2094$ & $0.0908,0.2587$ & $0.0657,0.1963$ \\
$R_{1}, \mathrm{w} R_{2}[$ all data] & $0.0865,0.2695$ & $0.0748,0.2193$ & $0.0995,0.2742$ & $0.0804,0.2118$ \\
\hline
\end{tabular}

Table $\mathrm{S}_{4}$ Crystallographic data of AlOC-23 to AlOC-26-NC

\begin{tabular}{|c|c|c|c|c|}
\hline & AlOC-23 & $\mathrm{AlOC}-24$ & AlOC-25 & AlOC-26-NC \\
\hline Empirical formula & $\mathrm{C}_{96} \mathrm{H}_{104} \mathrm{Al}_{8} \mathrm{~N}_{16} \mathrm{O}_{24}$ & $\mathrm{C}_{72} \mathrm{H}_{96} \mathrm{Al}_{8} \mathrm{~N}_{16} \mathrm{O}_{24} \mathrm{~S}_{8}$ & $\mathrm{C}_{72} \mathrm{H}_{72} \mathrm{Al}_{8} \mathrm{~N}_{16} \mathrm{O}_{32}$ & $\mathrm{C}_{88} \mathrm{H}_{92} \mathrm{Al}_{8} \mathrm{~N}_{16} \mathrm{O}_{26}$ \\
\hline Formula weight & 2081.79 & 2041.96 & 1889.29 & 2005.61 \\
\hline Temperature / K & $110.30(18)$ & $100.6(9)$ & $110.38(12)$ & $100.0(5)$ \\
\hline Crystal system & tetragonal & tetragonal & tetragonal & cubic \\
\hline Space group & $\mathrm{P}_{4} / \mathrm{nnc}$ & $P_{4} / \mathrm{nnc}$ & $P_{4} / \mathrm{nnc}$ & $P_{432}$ \\
\hline$a[\AA]$ & $17 \cdot 4769(14)$ & $15 \cdot 9689(13)$ & $15.6793(2)$ & $21.1973(6)$ \\
\hline$b[\AA]$ & $17 \cdot 4769(14)$ & $15 \cdot 9689(13)$ & $15.6793(2)$ & $21.1973(6)$ \\
\hline$c[\AA]$ & $20.492(4)$ & $20.5784(3)$ & $20.4859(3)$ & $21.1973(6)$ \\
\hline$\alpha\left[^{\circ}\right]$ & 90 & 90 & 90 & 90 \\
\hline$\beta\left[^{\circ}\right]$ & 90 & 90 & 90 & 90 \\
\hline$\gamma\left[^{\circ}\right]$ & 90 & 90 & 90 & 90 \\
\hline$V\left[\AA^{3}\right]$ & $6259.1(16)$ & $5247 \cdot 59(11)$ & $5036.26(15)$ & $9524 \cdot 5(8)$ \\
\hline$Z$ & 2 & 2 & 2 & 3 \\
\hline$\rho_{\text {calcd }}\left[\mathrm{g} \mathrm{cm}^{-3}\right]$ & 1.105 & 1.292 & 1.246 & 1.049 \\
\hline$\mu\left[\mathrm{mm}^{-1}\right]$ & 0.749 & 1.827 & 0.937 & 0.736 \\
\hline \multirow[t]{2}{*}{$F($ oоo $)$} & 2176.0 & 2128.0 & 1952.0 & 3132.0 \\
\hline & $-22 \leq h \leq 15$ & $-18 \leq h \leq 18$ & $-17 \leq h \leq 18$ & $-26 \leq h \leq 27$ \\
\hline \multirow[t]{2}{*}{ Index ranges } & $-22 \leq \mathrm{k} \leq 21$ & $-17 \leq \mathrm{k} \leq 16$ & $-19 \leq \mathrm{k} \leq 20$ & $-26 \leq k \leq 15$ \\
\hline & $-26 \leq 1 \leq 25$ & $-17 \leq 1 \leq 24$ & $-22 \leq 1 \leq 26$ & $-19 \leq 1 \leq 14$ \\
\hline Reflections collected & 21302 & 16530 & 19658 & 15012 \\
\hline Independent refs $\left[\mathrm{R}_{\mathrm{int}}\right]$ & $3574[0.0515]$ & $2250[0.0274]$ & $2852[0.0325]$ & $3608[0.0629]$ \\
\hline data/restraints/parameters & $3574 / 4 / 170$ & $2250 / 6 / 147$ & $2852 / 3 / 151$ & $3608 / 0 / 157$ \\
\hline Goodness-of-fit on $F^{2}$ & 1.042 & 1.841 & 1.080 & 1.071 \\
\hline$R_{1}, \mathrm{w} R_{2}[\mathrm{I}>2 \sigma(I)]$ & $0.0843,0.2778$ & $0.1095,0.3707$ & $0.0732,0.2364$ & $0.0495,0.1376$ \\
\hline$R_{1}, \mathrm{w} R_{2}$ [all data] & $0.1280,0.3400$ & $0.1146,0.3831$ & $0.0804,0.2463$ & $0.0621,0.1432$ \\
\hline
\end{tabular}


Table $\mathrm{S}_{5}$ Crystallographic data of AlOC-27-NC to $\mathbf{I}_{\mathbf{2}} @ \mathrm{AlOC}-27-\mathrm{NC}$

\begin{tabular}{|c|c|c|c|c|}
\hline & AlOC-27-NC & AlOC-28-NC & AlOC-29-NC & $\mathrm{I}_{2} @ \mathrm{AlOC}-27-\mathrm{NC}$ \\
\hline Empirical formula & $\mathrm{C}_{8 \mathrm{o}} \mathrm{H}_{64} \mathrm{Al}_{8} \mathrm{Cl}_{8} \mathrm{~N}_{16} \mathrm{O}_{24}$ & $\mathrm{C}_{80} \mathrm{H}_{64} \mathrm{Al}_{8} \mathrm{Br}_{8} \mathrm{~N}_{16} \mathrm{O}_{24}$ & $\mathrm{C}_{80} \mathrm{H}_{56} \mathrm{Al}_{8} \mathrm{I}_{8} \mathrm{~N}_{16} \mathrm{O}_{24}$ & $\mathrm{C}_{80} \mathrm{H}_{56} \mathrm{Al}_{8} \mathrm{Cl}_{8} \mathrm{I}_{2} \mathrm{~N}_{16} \mathrm{O}_{24}$ \\
\hline Formula weight & 2132.91 & 2488.59 & 2856.44 & 2378.64 \\
\hline Temperature / K & $110.00(10)$ & $293(2)$ & $293(2)$ & $109.99(10)$ \\
\hline Crystal system & cubic & cubic & cubic & cubic \\
\hline Space group & $P_{432}$ & $P_{432}$ & $P_{432}$ & $P_{432}$ \\
\hline$a[\AA]$ & $21.0460(2)$ & $21.1427(2)$ & $21.3205(3)$ & $20.9927(3)$ \\
\hline$b[\AA]$ & $21.0460(2)$ & $21.1427(2)$ & $21.3205(3)$ & $20.9927(3)$ \\
\hline$c[\AA]$ & $21.0460(2)$ & $21.1427(2)$ & $21.3205(3)$ & $20.9927(3)$ \\
\hline$\alpha\left[^{\circ}\right]$ & 90 & 90 & 90 & 90 \\
\hline$\beta\left[^{\circ}\right]$ & 90 & 90 & 90 & 90 \\
\hline$\gamma\left[^{\circ}\right]$ & 90 & 90 & 90 & 90 \\
\hline$V\left[\AA^{3}\right]$ & $9322.0(3)$ & 9451.1(3) & $9691.5(4)$ & $9251.3(4)$ \\
\hline$Z$ & 3 & 3 & 3 & 3 \\
\hline$\rho_{\text {calcd }}\left[\mathrm{g} \mathrm{cm}^{-3}\right]$ & 1.140 & 1.312 & 1.468 & 1.281 \\
\hline$\mu\left[\mathrm{mm}^{-1}\right]$ & 1.774 & 2.790 & 10.761 & 4.423 \\
\hline$F(\mathrm{ooo})$ & 3264.0 & 3696.0 & 4104.0 & 3558.0 \\
\hline \multirow{3}{*}{ Index ranges } & $-27 \leq \mathrm{h} \leq 27$ & $-26 \leq h \leq 27$ & $-27 \leq h \leq 14$ & $-27 \leq h \leq 27$ \\
\hline & $-27 \leq \mathrm{k} \leq 18$ & $-26 \leq \mathrm{k} \leq 27$ & $-27 \leq \mathrm{k} \leq 27$ & $-27 \leq \mathrm{k} \leq 27$ \\
\hline & $-14 \leq 1 \leq 27$ & $-27 \leq 1 \leq 27$ & $-26 \leq 1 \leq 27$ & $-25 \leq 1 \leq 27$ \\
\hline Reflections collected & 29757 & 79087 & 34630 & 130298 \\
\hline Independent refs $\left[\mathrm{R}_{\mathrm{int}}\right]$ & $3599[0.0690]$ & $3670[0.0436]$ & $3723[0.0426]$ & $3588[0.0692]$ \\
\hline data/restraints/parameters & $3599 / 0 / 156$ & $3670 / 0 / 155$ & $3723 / 6 / 155$ & $3588 / 0 / 161$ \\
\hline Goodness-of-fit on $F^{2}$ & 1.025 & 1.072 & 1.079 & 1.1461 \\
\hline$R_{1}, \mathrm{w} R_{2}[I>2 \sigma(I)]$ & $0.0523,0.1421$ & $0.0361,0.1083$ & $0.0693,0.2108$ & $0.0861,0.2405$ \\
\hline$R_{1}, \mathrm{w} R_{2}$ [all data] & $0.0696,0.1567$ & $0.0376,0.1098$ & $0.0739,0.2157$ & $0.0905,0.2476$ \\
\hline
\end{tabular}

Table S6 Crystallographic data of $\mathbf{I}_{\mathbf{2}} @$ AlOC-28-NC

\begin{tabular}{ll}
\hline & $\mathrm{I}_{2} @ \mathrm{AlOC}-28-\mathrm{NC}$ \\
\hline Empirical formula & $\mathrm{C}_{80} \mathrm{H}_{56} \mathrm{Al}_{8} \mathrm{Br}_{8} \mathrm{I}_{2} \mathrm{~N}_{16} \mathrm{O}_{24}$ \\
Formula weight & $2734 \cdot 32$ \\
Temperature / K & $120.00(11)$ \\
Crystal system & cubic \\
Space group & $P 432$ \\
$a[\AA]$ & $21.1250(\mathrm{o})$ \\
$b[\AA]$ & $21.1250(\mathrm{o})$ \\
$c[\AA]$ & $21.1250(\mathrm{o})$ \\
$\alpha\left[^{\circ}\right]$ & 90 \\
$\beta\left[^{\circ}\right]$ & 90 \\
$\gamma\left[^{\circ}\right]$ & 90 \\
$V\left[\AA^{3}\right]$ & $9427.2(\mathrm{o})$ \\
$Z$ & 3
\end{tabular}


$\rho_{\text {calcd }}\left[\mathrm{g} \mathrm{cm}^{-3}\right]$

$\mu\left[\mathrm{mm}^{-1}\right]$

$F$ (ooo)

Index ranges

Reflections collected

Independent refs $\left[\mathrm{R}_{\text {int }}\right]$

data/restraints/parameters

Goodness-of-fit on $F^{2}$

$R_{1}, \mathrm{w} R_{2}[I>2 \sigma(I)]$

$R_{1}, \mathrm{w} R_{2}$ [all data]
1.445

5.455

3990.0

$-27 \leq \mathrm{h} \leq 16$

$-27 \leq \mathrm{k} \leq 27$

$-27 \leq 1 \leq 24$

141409

3674 [0.0503]

$3674 / 0 / 161$

1.296

$0.0616,0.2336$

$0.0623,0.2345$ 